\title{
THE EVOLUTION AND IMPACT OF TOURISM IN THE MEDITERRANEAN: THE CASE OF ISLAND REGIONS, 1990-2002
}

\author{
Carles Manera ${ }^{2}$ \\ Jaume Garau ${ }^{3}$ \\ Universitat de les Illes Balears \\ Eloi Serrano 4 \\ Universitat Pompeu Fabra. Barcelona
}

\begin{abstract}
This paper aims to analyse one of the world's top tourist destinations, the Mediterranean, and, more specifically, the evolution and impact of mass tourism on its western islands (Corsica, Sardinia, Sicily, Malta and the Balearic Islands) throughout the final decade of the 20 th century. Firstly a general overview of world tourism is given, followed by an analysis of tourism in the Mediterranean. In continuation, an in-depth study is made of the evolution and impact of tourism on the aforementioned islands. Finally, possible signs of Dutch disease are examined in these island regions, since their economies have taken advantage of natural resources in the development of their tourist industries, but overspecialization might well jeopardize their future development.
\end{abstract}

Keywords: Mediterranean; Balearic Islands; Malta; Sardinia; Sicily; Corsica; destination lifecycle; mass tourism; IMEDOC; Dutch disease.

Received: 4 March 2015

Returned for revision: 6 May 2015

Accepted: 15 June 2015

1 This study is part of the research project HAR2015-64769-P, directed by Dr. Jordi Catalan Vidal. We thank to Ministerio de Economía y Competitividad for your support.

2 Departamento de Economía Aplicada. Universitat de les Illes Balears. Carretera de Valldemossa, km 7.5. 07122 PALMA DE MALLORCA (Spain).E-mail: carles.manera@uib.es

3 Departamento de Economía Aplicada. Universitat de les Illes Balears. Carretera de Valldemossa, km 7.5. 07122 PALMA DE MALLORCA (Spain).E-mail: carles.manera@uib.es

4 Escola Superior de Ciències Socials i Empresa Tecnocampus. Universitat Pompeu Fabra. Av. Ernest Lluch, 32.08302 Mataró. BARCELONA (Spain)..E-mail: eserrano@tecnocampus.cat 


\section{La evolución y el impacto del turismo en el Mediterráneo: el caso de las regiones insulares, 1990-2002}

\section{RESUMEN}

El presente trabajo tiene como objetivo analizar uno de los destinos turísticos más importantes del mundo, el Mediterráneo, y, más concretamente, la evolución y el impacto del turismo de masas en sus islas occidentales (Córcega, Cerdeña, Sicilia, Malta y las Islas Baleares) a lo largo de la última década del siglo XX. Primeramente se da una visión general del turismo mundial, seguido de un análisis del turismo en el Mediterráneo. A continuación, se realiza un estudio en profundidad sobre la evolución y el impacto del turismo en las islas mencionadas. Por último, se identifican los posibles signos de enfermedad holandesa en estas regiones insulares, ya que sus economías se han aprovechado de los recursos naturales en el desarrollo de sus industrias turísticas, pero la sobre especialización bien podría poner en peligro su futuro desarrollo.

Palabras clave: Mediterránea; Islas Baleares; Malta; Cerdeña; Sicilia; Córcega; del ciclo de vida de destino; el turismo de masas; IMEDOC; la enfermedad holandesa.

\section{INTRODUCTION}

Tourism is one of today's major, most dynamic economic activities. As an example, in 2002 a total of 703 million international tourist trips were recorded throughout the world. This represents $7 \%$ of the said year's world exports of goods and services. Within this context, one of the world's key areas is the Mediterranean, which accounts for one third of all tourist arrivals. In turn, within the Mediterranean its western islands are unique examples of the development of a tourism economy, with a blend of features that include pioneering experience, specialization and economic diversification. Although the islands' growth models have evolved differently, in economic terms they are based on solid historical foundations (Cancila, 1995; Ruju, 1998; Manera, 2001; Butera-Ciaccio, 2002). It is within this framework that voices speak of over-dependence on a single economic sector (mass tourism), intensive processes of de-industrialization, a shift towards the tertiary sector, a mature phase of tourism growth and even economic «diseases». Thus the relevance of our proposed study: an analysis of the impact, costs and benefits of tourism in recent years in the Balearic Islands, Sardinia, Corsica, Malta and Sicily.

The study is divided into five sections. The first gives a general overview of world tourism, followed by an analysis of tourism in the Mediterranean. It then offers an indepth insight into the case of the aforementioned islands, before exploring the theoretical model known as «Dutch disease» (Corden, 1984; Corden-Neary, 1982) and possible signs of its presence in the said economies. Finally the main conclusions of the study are described. The research work focuses on the following areas. Firstly, at a regional level for France, Italy and Spain, it uses Eurostat data to examine the current composi- 
tion and recent evolution of the Gross Value Added (GVA), at basic prices, of sixteen fields of activity. Secondly, two indicators are formulated (described in the following pages) to examine the environmental impact of tourism. Systematized variables (taken from official WTO publications, detailed in the final bibliography) were chosen, based on the contributions of other experts on tourism economics and on the availability of series of data (given the number of cases under observation and the time span that was used), in order to obtain magnitudes that could be compared. These magnitudes were the number of international arrivals, overnight stays, tourist spending in the reference country and the number of tourist beds. The study concentrates on an analysis of the tourism demand, since most specialist literature concludes that variations in the tourism demand lead to changes in the supply and not vice versa. Finally, the period under analysis (1990-2002) is crucial in changes detected in tourism markets from the late 20th century onwards (Rosselló, 2003). Thus both the focus of this study, Mediterranean islands and their setting, and the selected time span are appropriate choices for an analysis of the fixed and changing features of mature tourism economies and economies in the process of expansion.

\section{A GLOBAL OVERVIEW OF WORLD TOURISM}

Most studies of the tourism demand define it as being conditioned by income and prices. Since it has an income elasticity greater than one, tourism is classified a luxury good. Its price elasticity, however, tends to be more irregular, with the price factor being less important in long-duration travel and a higher price elasticity in the case of short-haul destinations (Rosselló, 2003). Nonetheless, from a historical perspective, the growth in the volume of international tourists is higher than the growth of the world economy. In the last fifty years, for every $1 \%$ rise in the per capita income of the world's inhabitants, the number of travellers has risen by over $3 \%^{5}$ (see Figure 1). WTO forecasts, which predict a growth in world tourism close to $4 \%$ (rising from 702 million tourists in 2002 to 1,561 by 2020), are based on a rise in citizens' available income and on certain socio-demographic changes occurring in more developed countries (an increase in the number of childless couples and one-family homes, better levels of education, a higher proportion of older people and rising numbers of pensioners). Nevertheless, other factors also affect this plausible forecast of a growth in the number of tourists over the next few years:

1. Falling tourist expenditure in destinations. Tourist expenditure is a difficult variable to interpret because it is influenced by fluctuations in the exchange rate and price rises in tourist products. Over the last decade, however, there has been a clear trend toward a reduction in the length of stay at destinations (Alegre-Pou, 2003a). Thus basing total tourist expenditure on daily per capita tourist spending, the average length of stay and

$5 \quad$ Between 1950 and 2001, the world's per capita GDP rose by about $2.1 \%$ and the number of tourists by $7 \%$, although the trend was not constant over this period. While from 1950-1973 there was a $2.9 \%$ rise in per capita income, with an increase in the volume of tourists of almost 10\%, the period spanning 1973-2001 saw an annual increase in the per capita world GDP of $1.4 \%$. This led to a $50 \%$ drop in tourist travel, with an annual growth of around 5\% (Maddison, 2003; Anisi, 2005). 


\section{Figure 1 \\ WORLD ECONOMIC GROWTH \& INCREASE \\ IN TOURIST ARRIVALS, 1950-2002}

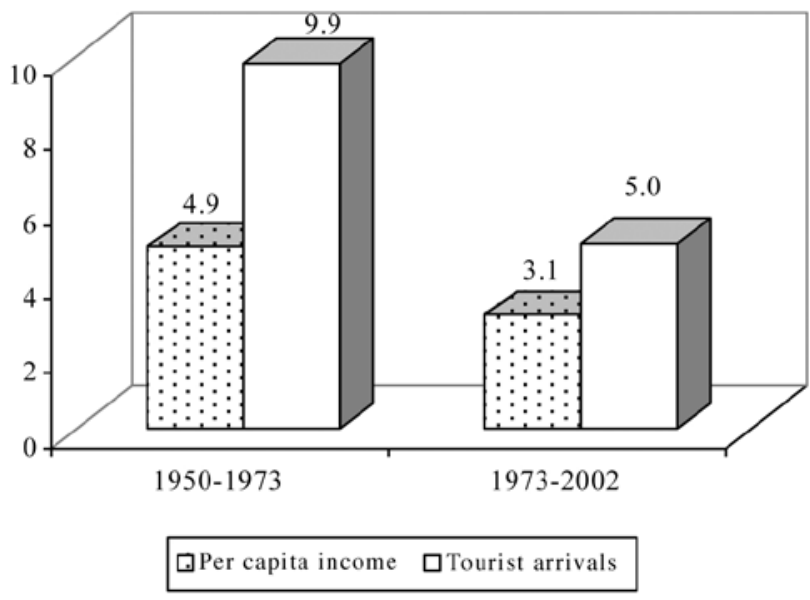

Source: Own, from World Tourism Organization data (henceforth WTO) \& Maddison (2003).

the number of tourist arrivals, in recent years it has been noted that the growth in tourist spending is not proportional to the increase in the number of visitors. The reasons for the reduced length of stay include:

- The greater frequency of international travel, involving a reduction in the length of each stay.

- A tourist preference for better quality holidays, which entails giving up longer stays.

- The existence of a price-effect that might encourage a reduction in the length of stay at a destination.

2. Less correlation between the number of international arrivals and the number of tourists. Misleadingly, these two figures have always been regarded as synonymous. That is, visitors staying for over one night in a country were considered to be on a leisure or holiday trip and thus highly likely to consume goods and services. Over the last few years, however, there has been a significant drop in this kind of traveller, falling from $62 \%$ of all tourist arrivals in 1990 to $54 \%$ in 2001 . On the other hand, there has been a sharp rise in the number of people travelling for business or professional motives or for family or health purposes, who are included in the international tourist arrivals category. These travellers rose from $29 \%$ in 1990 to $43 \%$ in 2001 . In a world that is increasingly globalized, the upturn in this kind of traveller is logical ${ }^{6}$.

\footnotetext{
6 International tourist arrivals rose by $4.2 \%$ between 1990 and 2000 and holiday and leisure travel by
} $2.7 \%$. 
3. Signs of maturity in the tourism demand of certain countries. Analyses of the behaviour of issuing tourism and other recent studies (European Commission, 1998; Alegre-Pou, 2003a; a general overview in Vellas, 2004) indicate a possible slowdown in the percentage of the population who travel abroad in the issuing markets of developed countries. France and Great Britain are good examples, where the increase in the tourism demand can be attributed to a greater number of yearly trips by habitual travellers. Between 1990 and 2002 the world regions that experienced the biggest rise in the number of issuing tourists were Asia and the Pacific, with an increase of $118 \%$ (passing from 60 million to over 131 million tourists), and the Middle East, with a rise of 100\% (from 8 to 16 million tourists). Europe and America have seen a lower rise, with respective figures of $53 \%$ and $21 \%$, passing from 363 to 525 million tourists (see Figure 1).

Table 1

TOURISM BY ISSUING REGIONS, 1990-2002 (THOUSANDS OF TOURISTS)

\begin{tabular}{|l|c|c|c|}
\hline & $\mathbf{1 9 9 0}$ & $\mathbf{1 9 9 5}$ & $\mathbf{2 0 0 2}$ \\
\hline Africa & 9.9 & 12.8 & 16.8 \\
America & 99.2 & 107.9 & 120.2 \\
Asia-Pacific & 60.2 & 89.8 & 131.2 \\
Europe & 263.9 & 317.6 & 404.9 \\
Middle East & 8 & 9.5 & 16 \\
Unspecified & 14.7 & 12.9 & 13.5 \\
World total & 455.9 & 550.4 & 702.6 \\
\hline
\end{tabular}

Source: WTO.

4. A shift in world tourism. In 2002, the world's top ten tourist destinations received $50 \%$ of all international visitors, who in turn accounted for over half the world's tourist expenditure (see Ramón, 2002). Nine of these top ten destinations are countries in Europe or places in the United States. However, if we look at tourism economics from a historical perspective, Europe and America have fallen in importance as destinations. In 1950, the two continents accounted for $97 \%$ of all world tourism, whereas by the year 2000 the percentage had dropped to $78 \%$ and, according to WTO forecasts, by 2020 it will have fallen still further to $64 \%{ }^{7}$. Asia and the Pacific are at the other extreme, rising spectacularly in importance from $1 \%$ in 1950 to $17 \%$ in 2000, with a forecasted figure of $27 \%$ by 2020 . The Middle East and Africa have followed a similar trend, doubling in importance as tourist destinations with further expected future success. Consequently, a reduction in Europe and America's market share can be observed (Figure 2) and tourism growth is undergoing a process of peripherization (see the scenario described by Fernández Fuster, 1991).

7 A recent time series analysis of world tourism in Papatheodorou-Song, 2005. 
Figure 2

INTERNATIONAL TOURIST ARRIVALS TO DIFFERENT WORLD REGIONS, 1950-2002 AND 2003-2020 FORECASTS

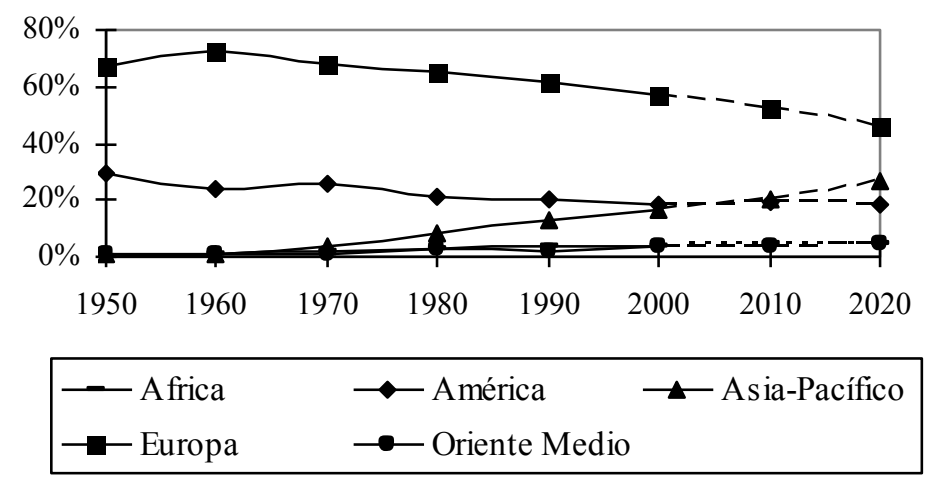

Source: WTO.

5. New consumer preferences. Based on the paradigm of the mature lifecycle stage of a tourist destination (Butler, 1980) ${ }^{8}$, the hypothetical emergence of a «new tourist» has been posed: one with more experience and a greater ecological awareness who shuns mass tourism (Poon, 1993). These tourists, classed «post-Fordists» (Poon, 1993; IoannidesDebagge, 1998; Ramón, 2002), have interests other than congested sun and sand resorts, and they therefore represent a serious threat for mass tourist destinations. Nonetheless, this theory needs putting into perspective:

a) There is a wide diversity of current and potential future tourists. Not only can this help limit the decline of mature destinations, but it can facilitate the emergence of new ones.

b) The growth of this last group of destinations can be explained by:

- A demand segment in traditional issuing countries (Europe and America) that shuns mass tourism in search of another form of travel. These tourists opt for long-haul destinations outside the world region in which they live.

- Citizens with available incomes from Africa, the Middle East, and Asia and the Pacific (particularly Asia with its wide-ranging territories) who are just beginning to travel in large numbers. They tend to favour destinations close to their own countries.

8 R. W. Butler proposes six stages in tourism economies, characterized by different growth rates in the demand. During the first stage, known as the «exploration» stage, there are few tourists and so scarcely any changes take place. During the second «involvement» stage, the number of visitors starts to grow at an increasing rate until the destination reaches the third peak «development» stage. From then on the number of tourists grows but at a slower rate, followed shortly afterwards by a halt in growth when the period that Butler calls the «stagnation» stage is reached. Lastly there are two possibilities: «rejuvenation» or «decline». The whole cycle has a high capacity as an explanatory framework for certain tourism economies in the Mediterranean, particularly those that have reached a high level of maturity. 


\section{THE MEDITERRANEAN AS A TOURIST DESTINATION}

Despite the figures outlined above, the historical and economic area that the Mediterranean represents still holds major appeal for the leisure market ${ }^{9}$. The Mediterranean Basin comprises a total of twenty-two states ${ }^{10}$, all of which border the Mare Nostrum. In conjunction, these countries form one of the world's top tourist destinations, registering over 702 million visitors in 2002 (one third of all the world's international tourist arrivals) and revenue from tourism of 134 billion dollars (28\% of world tourist expenditure). Evidently, the Mediterranean bases a large part of its economic activity on tourism services. In the same year, tourism in these countries accounted for about 3.7\% of the GDP. No one can dispute the variety that the Mediterranean offers. From traditional sun and sand destinations (like Spain, Turkey and Tunisia) to those with a high cultural or heritage-based component (in particular France and Italy), the Mediterranean's coastal areas are mainly visited for holiday and leisure purposes, although other incentives are gradually gaining ground, as is also occurring at a world level, such as travel for health purposes or professional and business reasons. This leads to a greater diversity of destinations and customer typologies. Europeans are the most assiduous visitors (nine out of ten tourists), with the Americans far behind them (less than 5\%). More recently, a boom in tourists from the Middle East and Southeast Asia has been detected: a group that doubled its market share between 1990 and 2002 (rising from 7 to 13 million arrivals).

The strength of the Mediterranean's tourist industry is confirmed by its current seven million tourist beds, mainly concentrated (two out of every three) in France, Spain and Italy. Despite this remarkable vigour, the statistics analysed in this study herald changes:

1. The Mediterranean is still a major world tourist destination, despite a current process of internal recomposition. Between 1990 and 2002, the Mediterranean as a whole echoed the world trend in tourist arrivals and tourist expenditure. Whilst the Mediterranean saw an increase in tourist arrivals of $51.7 \%$ and the world an increase of $54.1 \%$, tourist expenditure underwent a respective increase of $79 \%$ and $79.5 \%$. At the same time, the Mediterranean also followed the process of peripherization that world tourism was undergoing, as described above. The three top destinations (France, Spain and Italy) experienced a $49 \%$ increase in tourist arrivals, with figures that rose from 113 to 169 million visitors. The Mediterranean's remaining countries saw a 59\% rise, moving from 37 to 59 million tourists. This process is confirmed by the flow of investments, with less growth in tourist accommodation in traditional destinations (16\% or 640,000 new beds) and a $52 \%$ rise or 800,000 new beds in the Mediterranean's remaining countries. Two factors should be noted:

9 A recent analysis of the impact of tourism in the Mediterranean from the perspective of socioeconomic and cultural development, in Apostolopoulos-Loukissas-Leontidou, 2001.

10 Albania, Algeria, Cyprus, Egypt, Spain, France, Greece, Israel, Italy, Libya, Lebanon, Malta, Morocco, Monaco, Palestine (which is not included in the compiled data, since complete series were unavailable), Syria, Tunisia, Turkey and the following ex-Yugoslavian states: Bosnia-Herzegovina, Croatia, Slovenia and Serbia \& Montenegro (although data was taken for Yugoslavia as a whole until 1991). Exceptionally, Macedonia was also included, even though it is not a coastal Mediterranean country, in order to standardize the variables for the exYugoslavia. 
a) Booming numbers of tourists from new issuing markets, with increasing visitors to the Mediterranean from the Middle East and Southeast Asia (reflected by a growth rate of $95 \%$ between 1990 and 2002). Over the same period, visitor numbers from Europe and America slowed down, rising by just $16 \%$ (see Figure 3).

Figure 3

ANNUAL GROWTH RATES OF VISITORS TO THE MEDITERRANEAN BY ISSUING REGIONS, 1990-2002

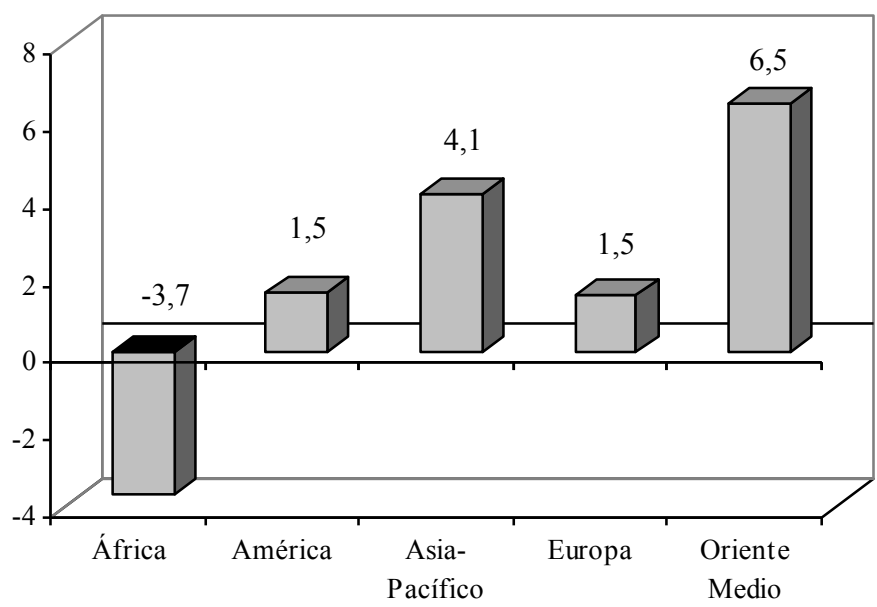

Source: Own based on WTO data.

b) A change in European tourism consumers' choice of destination, with a growing preference for other areas of the Mare Nostrum. In the course of a few years, the percentage of Europeans travelling to the three traditional destinations has changed: in $1990,88 \%$ of European visitors to the Mediterranean chose France, Spain or Italy as destinations but by 2002 this percentage had fallen to $77 \%$. In short, a slight yet tangible change can be observed in a certain segment of the tourism demand.

2. The rising importance and spread of tourism as an economic activity, plus growing environmental repercussions. In 1990, tourist expenditure accounted for $2.3 \%$ of the GDP, while by 2002 this figure had risen to $3.7 \%$. This aggregate figure is highly significant, but a breakdown offers an even better insight: in 1990 just five Mediterranean countries had a tourist expenditure equivalent to over 5\% of their respective incomes whereas by 2002 this situation was applicable to twelve different nations. Tourist expenditure in BosniaHerzegovina, Croatia, Syria and Turkey has increased its share of the GDP, accompanied by a sharp rise in the number of international tourist arrivals and overnight stays, with growth rates of between $250 \%$ and $400 \%$, far above the Mediterranean average of $65 \%$.

Nonetheless, this growth in tourism, albeit with fluctuating figures as shown above, has other logical consequences that must also be taken into consideration since they 
affect factors that play a decisive role in the quality of the tourism product. Clearly we are referring to the environmental externalities of these tertiary activities, which can be seen to extend along the entire length of the Mediterranean coast. From among different measures of sustainability in service economies (Azar et alter, 1996; Jacobs, 1996; Agenda Local 21, 1999; Hanley et alter, 1999; Van der Bergh-Verbruggen, 1999; Manera-Riera, 2001; Blázquez-Garau-Murray, 2003), two synthetic indicators are proposed, aimed at establishing the level of population congestion and overdevelopment. That is, magnitudes implying processes lacking in sustainability. These indicators are the Human Impact Indicator (HII) and the Concentration of Tourist Accommodation (CAT). The first measures the real increase in a region's population when its floating population is also included. It is formulated as follows:

$$
\mathrm{HII}=\frac{\text { Resident }+ \text { floating population }}{\text { Resident population }} * 100
$$

The second captures the number of tourist beds per square kilometre in a certain area, expressed as follows:

$$
\mathrm{CAT}=\frac{\text { Number of beds in all kinds of tourist accommodation establishments }}{\mathrm{km}^{2} \text { of country }}
$$

In the case of the HII, tourism has led to rising population congestion in the Mediterranean: the real population was $0.8 \%$ higher than the resident population in 2002, when in 1990 it had only been $0.48 \%$ higher (see Figure 4).

\section{Figure 4}

HUMAN IMPACT INDEX IN COUNTRIES OF THE MEDITERRANEAN, 2002

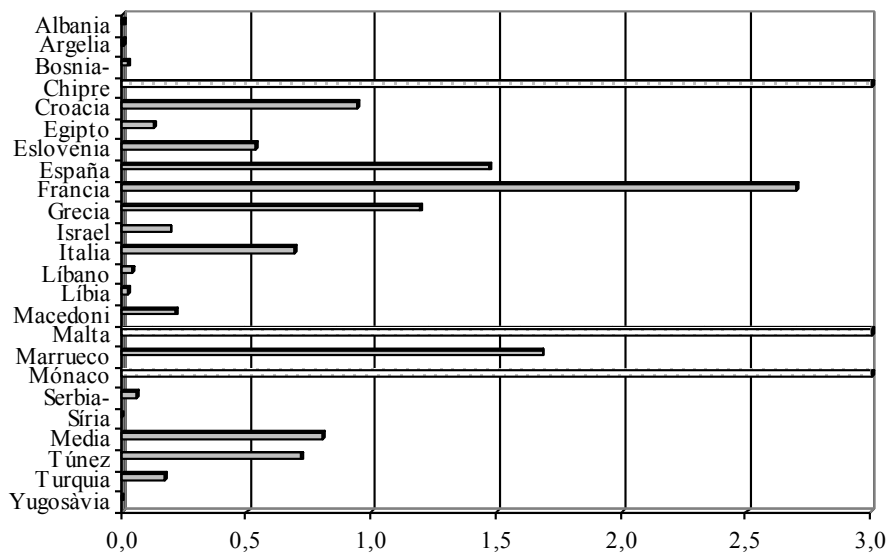

Source: Own based on WTO data.

Note: Cyprus, Monaco and Malta are not shown to scale since the corresponding figures are much higher than those of the other countries (14.1, 7.3 and 6.6 respectively). 
As for the CAT, in the Mediterranean there are 0.9 tourist beds per square kilometre, with a 20\% increase in beds having occurred between 1990 (when there were 0.75 beds) and 2002. This demonstrates the extent to which land has been developed. What is more, eleven countries have a CAT that doubles the Mediterranean average, when in 1990 this was only true of seven countries (see Figure 5). This in itself suggests clearly differing realities within the Mediterranean. By making a more detailed analysis, the countries of the Mediterranean can be tentatively classified according to their evolution and the state of their key tourism variables: international tourist arrivals, the total number of overnight stays and the number of tourist beds.

\section{Figure 5 \\ TOURIST BEDS PER KM², 2002}

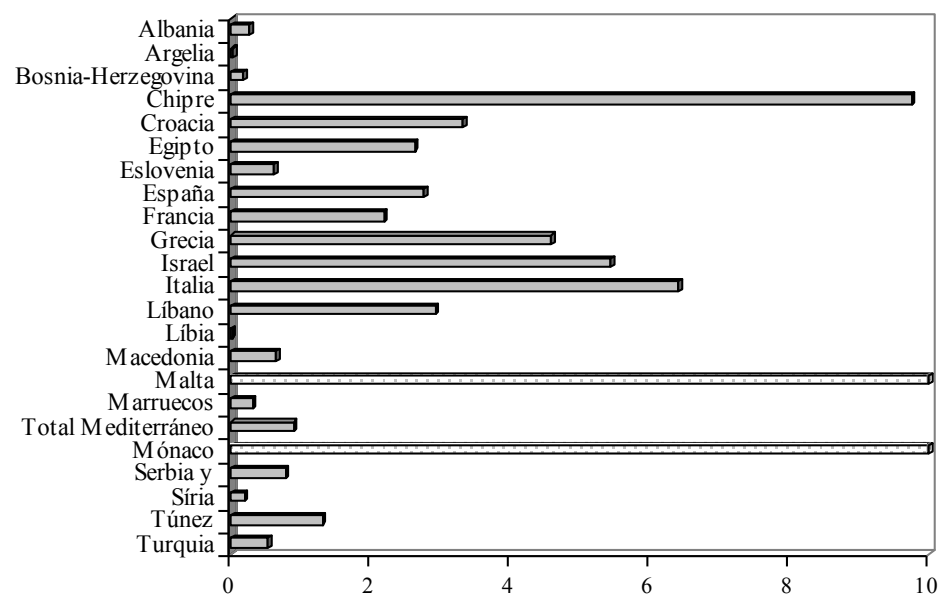

Source: Own based on WTO data.

Note: Monaco and Malta are not shown to scale since the corresponding figures are much higher than those of the remaining countries (1,096 and 128 tourist beds per $\mathrm{km}^{2}$ respectively).

a) The traditional leaders, France, Spain and Italy, which are clearly the Mediterranean's top destinations. They are also world leaders, sharing top position with the United States and China. All three are destinations that have had a long lifecycle, having followed a certain growth pattern for decades. The three countries have maintained their position as leaders, even though certain variables have risen at a lower rate than those of the remaining reference area, with a yearly increase of $3.1 \%$ in tourist numbers, $4.8 \%$ in overnight stays and $1.2 \%$ in accommodation. The corresponding figures for the Mediterranean as a whole are 3.3\%, $4.3 \%$ and $5.8 \%$. In short, in 2002 this trio accounted for $74.2 \%$ of all tourist arrivals to the Mediterranean, $79 \%$ of all overnight stays and $65.7 \%$ of all tourist accommodation: a situation very similar to that ten years previously, since in 1990 the corresponding figures were $75.5 \%, 74,4 \%$ and $71.8 \%$ (see Figure 6). 
b) Consolidated emerging destinations (CED): Croatia, Turkey, Egypt, Greece and Tunisia. The five countries can be distinguished from the rest (which have also seen a big rise in tourist numbers over the last few years) because they have followed a regular growth pattern that has remained constant for almost fifteen years. This leads us to regard them as emerging nations, yet with a consolidated tourism economy, because their evolution is not attributable to temporary scenarios but to decisive strategic bids by their authorities and economic agents. The figures for the CED are highly significant. In 2002 they received $16.2 \%$ of all tourists to the Mediterranean, accounting for $15.6 \%$ of all overnight stays and $24.4 \%$ of all tourist accommodation in the Mediterranean. The growth process in comparison with 1990 is evident, since in that year they accounted for $12.8 \%$ of all tourist arrivals, $12.5 \%$ of all overnight stays and $14.8 \%$ of the total accommodation supply. These countries' variables have seen a bigger rise than those of the rest of the Mediterranean (whose respective growth rates were 5.8, 6.1\% and $5.1 \%)$. See Figure 6.

\section{Figure 6}

\section{GROWTH RATES OF THE MAIN TOURIST VARIABLES, 1990-2002}

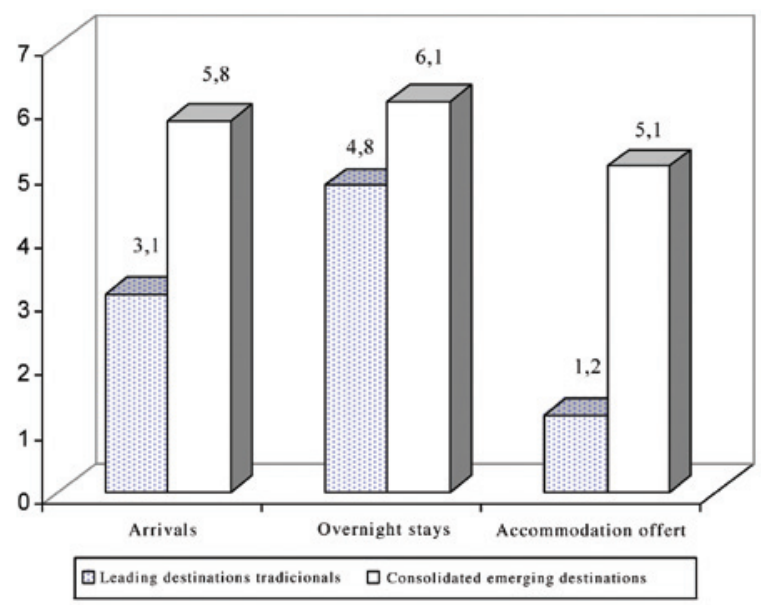

Source: Own based on WTO data.

c) Destinations with an erratic behaviour. These are countries (Albania, Algeria, Malta, Morocco and Monaco) whose tourism variables have increased at a slightly lower rate than the Mediterranean average or whose arrivals, overnight stays and tourist expenditure have fallen (like Israel). There are three basic reasons for these destinations' errant behaviour. The first is political instability, plus the appearance of violent phenomena of a political or religious nature. Examples are Algeria (where there were over one hundred thousand deaths in attacks by Islamic Fundamentalists between 1992 and 1998) and Israel (with the 
beginning of a new intifada in September 2000). Secondly, despite the growth of tourism in some of these countries (Algeria, Morocco), it has not maintained the same intensity or continued over such a long period of time as it has in CED countries. Finally, there are states (Malta, Monaco) with characteristics similar to those of traditional Mediterranean destinations. For years they have acted as references and now they are beginning to show signs of slower growth, with tourism figures below those of their Mediterranean rivals (Knickerbocker, 1973; Buckley-Brooke, 1988).

Lastly a separate mention must be made of the countries that make up the former Yugoslavia, because after the disappearance of this state in 1991 and the birth of the independent republics of Bosnia-Herzegovina, Croatia, Slovenia, Macedonia and Serbia \& Montenegro, one tourist destination was split into five. If they are viewed in perspective, it can be seen that after the logical increase in their tourism variables (given that all started out from almost zero after the Civil War), none has yet managed to pass the levels that Yugoslavia achieved in 1989. Indeed, the aggregate figures for all five of these new countries (8.9 million international tourist arrivals, 47 million overnight stays and 324,000 tourist beds) do not exceed the figures achieved by the ex -Yugoslavia in 1990, which stood at 9 and 52 million and 359,000 beds respectively.

\section{TOURISM IN WESTERN MEDITERRANEAN ISLANDS}

Within this dynamic context, the Mediterranean's island economies have played a special, albeit diverse role. Corsica, Sardinia, Malta and the Balearics are five island regions that initially seem to share comparable tourism characteristics: mild climates, good transport links with the main issuing markets for European tourism, political, social and economic stability and a large number of tourist beds. Not for nothing did these islands (henceforth the IMEDOC islands) account for over $8 \%$ of all international tourist arrivals to the Mediterranean, $7 \%$ of all overnight stays and $2.4 \%$ of all tourist beds in the Mare Nostrum in $2002^{11}$. In synthesis, after France, Spain and Italy, these islands are the Mediterranean's fourth tourist destination, with figures higher than those of Turkey, Croatia, Tunisia or Egypt.

Nonetheless, their individual tourist figures differ considerably. The Balearics is the leading archipelago in comparison with the rest. It accounts for over half the IMEDOC's tourist arrivals (9.6 million as opposed to an aggregate 18.7), most of their overnight stays (47 million as opposed to 88) and a large part of their tourist beds $(415,000$ beds out of $861,000)$. (See Figure 7). A more careful analysis leads to the following conclusions:

11 It is important to take into account that while figures for tourist arrivals and overnight stays in Mediterranean countries refer to international visitor arrivals (or non residents), in the case of its IMEDOC regions, the same variables also include domestic visitor arrivals. That is, they include tourists from Italy in the case of Sardinia and Sicily and their overnight stays, tourists from France in the case of Corsica, and tourists from Spain in the case of the Balearics. 
Figure 7

\section{THE MAIN TOURISM VARIABLES FOR IMEDOC REGIONS, 2002 (PERCENTAGE OF THE TOTAL)}

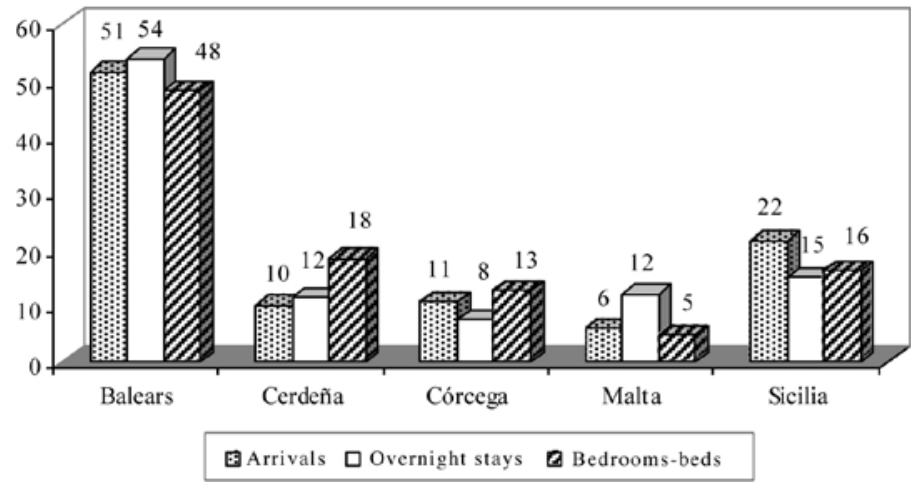

Source: Own based on Eurostat data.

1. High dependency on a small number of issuing markets. Out of almost 19 million tourist arrivals registered in these islands (2002), 80\% were from 5 countries alone: Italy (4.7 million), Germany (3.4), the United Kingdom (3.4), France (2.1) and Spain (1.4), followed at a considerable distance by Switzerland (0.4), Sweden (0.2) and Ireland (0.2). This heavy dependence is not quite the same in the cases of Sardinia, Corsica and Sicily, where between 65 and $70 \%$ of all arrivals are visitors from the islands' own country. The Balearics are in an intermediary position, although the German and British markets make up almost $60 \%$ of the demand there. Lastly, Malta is the archipelago where the greatest diversity was noted (see Figure 8).

\section{Figure 8}

COUNTRIES OF ORIGIN OF TOURIST ARRIVALS TO IMEDOC REGIONS, 2002

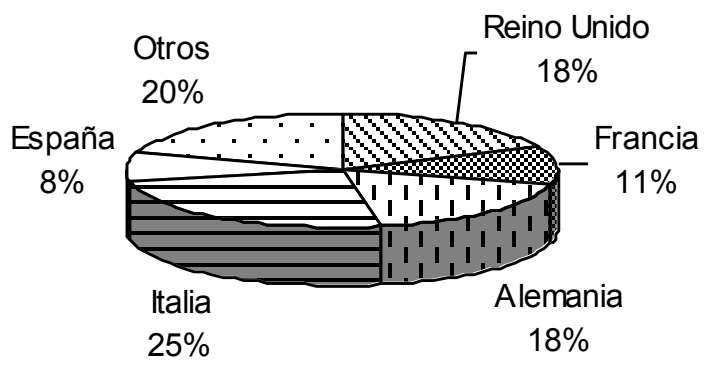

Source: Own based on data from the Institut Balear d'Estadística (IBAE) for the Balearics, National Statistics Office (NSO) for Malta, Sistema Statistico Nazionale (ISTAT) for Sardinia and Sicily and Institut national de la statistique et des études économiques (INSEE) for Corsica. 
2. Varying types of accommodation. The IMEDOC's tourism product varies from one island to another in terms of the accommodation that is available. Whereas Malta and the Balearics base their tourism product on hotels and similar types of accommodation (which represent $97 \%$ of all tourist beds in Malta and $74 \%$ in the Balearics), in Corsica, Sardinia and Sicily campsite accommodation plays a very important role, accounting for $55 \%, 42 \%$ and $29 \%$ of their respective accommodation supply. Even so, given the importance of the Balearics within the IMEDOC group, hotel beds account for most of the supply (5.5 million hotel beds or $63 \%$ of the accommodation supply). Nevertheless, it must be pointed out (Renucci, 2001) that in places with more campsite accommodation, this can influence the chosen means of transport used to reach the island. More passengers travel by sea to Sardinia, Sicily and Corsica than by air, and so many tourists who visit these islands come in their own vehicle. Other factors also clearly influence this, such as the higher number of domestic tourists and, by extension, the destinations' proximity.

3. Tourism's high environmental impact. Taking the HII and CAT as references, the results for the IMEDOC regions are highly illustrative. Population congestion for the IMEDOC is 3.7 times higher than the Mediterranean average. The Balearics and Malta are the most striking cases because, due to the effect of their floating populations (i.e. overnight tourist stays), the real population is $16 \%$ higher than the recorded population in the Balearics and 7.4\% in Malta. Corsica, Sardinia and Sicily experience a lower rise in their populations due to the lower number of overnight stays per inhabitant ${ }^{12}$. If we look at the physical side of tourism growth measured in terms of the CAT, the externalities are even higher for the IMEDOC islands than for the Mediterranean as a whole (even though the figure is particularly influenced by the situations of Malta and the Balearics). Whilst for the Mediterranean, the aggregate number of beds per square kilometre is below the unit, Malta and the Balearics have a recorded 129 and 83 beds per square kilometre. Although they exceed the Mediterranean average, Corsica, Sardinia and Sicily (13,7 and 5) are well behind their island counterparts in terms of land development for use as tourist accommodation (see Figure 9).

4. The seasonality of tourism. Reasons for visiting the IMEDOC islands include the appeal of their beaches and climates. As a result, the demand is strongly focused on the summer months when the weather is at its best. Although no aggregate data is available for the IMEDOC islands as a whole, the Balearics (which received $82 \%$ of all the year's tourist arrivals between May and June in 2002), Corsica (which received $80 \%$ of all the year's visitors over the same period) and Malta (whose tourist arrivals in the summer months of 2001 doubled its winter figures) show that tourism is concentrated into just a few weeks.

Moving beyond a static analysis, by looking at the evolution of tourism in the islands from 1990 to 2002, the behaviour of their tourism variables can be contextualized within the framework of the Mediterranean as a whole, leading to following conclusions:

a) As a Mediterranean destination, the IMEDOC have seen a fall in their market share. Despite the increase in overnight stays (24 million more overnight stays), the booming success of the CED (with a joint figure of 101 million overnight stays during the same period, doubling the 1990 figure) may have influenced this falling market share.

12 In the case of Corsica, the value of the HII is considered to have been overestimated given the region's low population, with a real density of population (the density of the recorded population + real population) of just 32.5 inhabitants per $\mathrm{km}^{2}$, as opposed to 1,356 inhabitants per $\mathrm{km}^{2}$ in the case of Malta or 187 in that of the Balearics. 


\section{Figure 9 \\ TOURIST BEDS PER KM²}

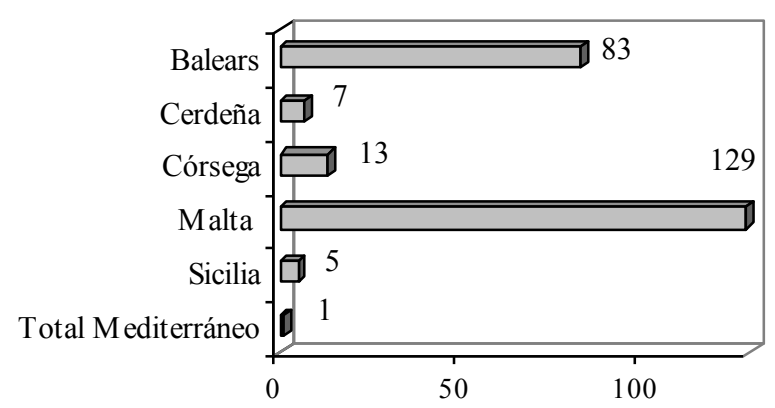

Source: Based on Eurostat and WTO data.

However, it should be noted that whilst the number of aggregate overnight stays in the Mediterranean as a whole rose by a yearly rate of $4.3 \%$, Sardinia, Corsica and Sicily experienced a rise of 3.4\%. Meanwhile, Malta and the Balearics saw a lower growth rate of $2.3 \%$ per year. Three facts can be confirmed by crossing data for the accommodation supply: firstly, the yearly rise in tourist beds in the Mediterranean, with an annual growth rate of $1.9 \%$, moving from a capacity of 5.4 million beds to 6.8 ; secondly, the fact that this growth has been polarized between traditional destinations (with 610,000 new beds and an annual growth rate of 1.2\%) and consolidated emerging nations (with 880,000 new beds and an annual growth rate of 5.8\%); and thirdly, that in Sardinia, Corsica and Sicily the accommodation supply has grown at an annual rate of $1.8 \%$ (84,000 new beds) whereas in the Balearics and Malta (with 27,000 new beds) the corresponding growth rate is only $0.5 \%$. Thus tourism capital has followed the same pattern as the demand.

b) The lower growth of tourist expenditure. Data is not available for tourist expenditure in all the islands, but the proposed hypothesis is that increases in tourist expenditure do not correspond with the number of tourist arrivals. This can be accounted for by the decrease in the average length of stay in the IMEDOC's top destinations, as will be seen, although the average length of stay in the Mediterranean as a whole has increased from 4.6 to 5.3 days ${ }^{13}$. In fact, the Mediterranean's island regions have followed a different pattern: in Malta and the Balearics the length of stay has fallen (from 5.4 to 4.9 , and 11 to 9.3 days respectively) and, predictably, tourist expenditure has risen at a lower rate, while in Sardinia, Corsica and Sicily the figure has remained stable ${ }^{14}$.

13 Own estimation, based on WTO figures.

14 According to the Survey on Tourist Expenditure conducted in the Balearics, there was an average length of stay of 10.24 days in 2002 and 13.14 days in 1989: figures accepted as realistic by the business sector and by experts. However, Eurostat figures have been used in order to guarantee a homogenous sequence for all the areas under study. Both sources point to the same trend: a reduction in the average length of stay by tourists to the Balearics. See Alegre-Pou, 2003a for more information. 
c) An improvement in occupancy rates. The lower rise in the creation of new tourist beds and the registered increase in overnight stays have led to a big rise in occupancy rates in tourist accommodation establishments. Whilst throughout 1990 there were 89 overnight stays per tourist bed in the Mediterranean, this figure rose to 174 in 2002. This trend is also applicable to the IMEDOC islands, although the best exponent is Corsica, where overnight stays per tourist bed rose from 32 to 61 . In Sicily there was a lower rise, moving from 89 to 94 overnight stays. In short, greater use seems to be being made of existing accommodation facilities.

Thus from an examination of the recent evolution of the islands' tourism variables, two different realities can be observed (see Figure 10). Firstly, Malta and the Balearic Islands can be seen to be mature leaders: archipelagos that occupy a dominant position, since between 1990 and 2002 they accounted for over 15 million more overnight stays. Nonetheless, given the fall registered since 1999, with a sluggish rise in tourist expenditure due to the significant decrease in the average length of stay and their falling market share (at a Mediterranean and IMEDOC level), these islands fit in with the behaviour typical of mature tourist destinations. It might be said that, to a certain extent, these areas have reached a threshold, where further growth cannot easily be achieved through an increase in tourist numbers and a resulting significant increase in tourist expenditure. At the same time, population congestion and a certain amount of environmental deterioration, with high levels of building and development, might handicap the search for new tourists from the medium to high income bracket, leading Malta and the Balearics to consolidate their traditional sun and sand model of tourism (see Figures 11 and 12). In second place, Corsica, Sardinia and Sicily are destinations in the process of expansion. In a context in which the IMEDOC are generally losing ground, these islands show better tourism indicators than the two leaders and they are following the same trend as the Mediterranean's remaining countries. They have experienced a 56\% increase in the number of tourists (as opposed to $52 \%$ for the Mediterranean as a whole and $49 \%$ for Malta and the Balearics), with a rise in overnight stays of 54\% (as opposed to $73 \%$ for the Mediterranean as a whole and $31 \%$ for Malta and the Balearics). In turn, they have seen a growth in tourist beds of $26 \%$ (in contrast with $27 \%$ for the Mediterranean and $6 \%$ for Malta and the Balearics) and an increase in the length of stay, with the positive repercussions that this

Figure 10

ANNUAL GROWTH RATES OF MAIN TOURISM VARIABLES, 1990-2002

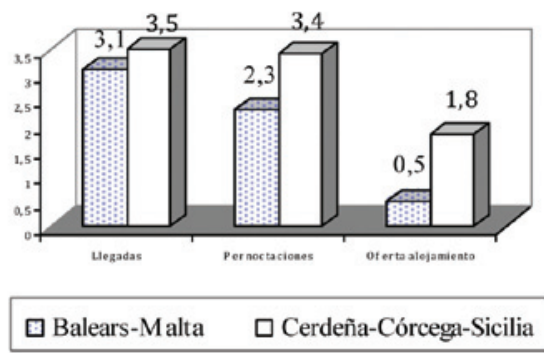

Source: Own based on Eurostat and WTO data. 
Figure 11

EVOLUTION OF OVERNIGHT STAYS IN THE BALEARICS, 1960-2002

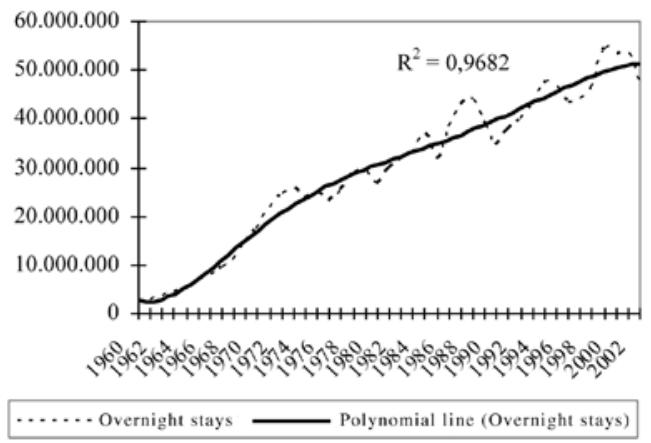

Source: Own based on Manera-Riera (2001) for 1960-1989 and Eurostat for 1990-2002.

Figure 12

EVOLUTION OF OVERNIGHT STAYS IN MALTA, 1960-2002

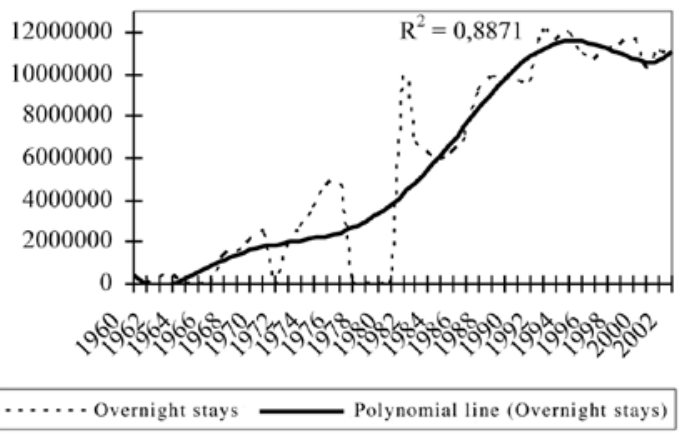

Source: Own based on WTO data.

Figure 13

OVERNIGHT STAYS IN IMEDOC REGIONS, 1990-2003

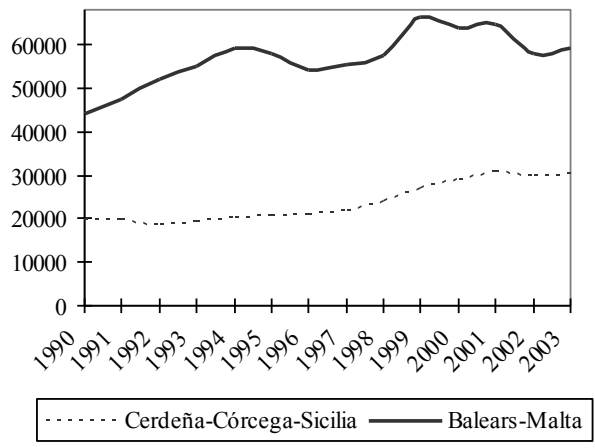

Source: Own based on Eurostat data. 
variable has on tourist expenditure in general. At the same time, it must be remembered that environmental indicators used to measure the impact of tourism show much lower saturation levels for Corsica, Sardinia and Sicily than for Malta and the Balearics. Misleadingly, the former seem to be undergoing a much more solid process of tourism growth with a higher competitive capacity than their more mature island counterparts. It should not be forgotten, however, that this might be because they are latecomers to the scene (see Figure 13).

\section{DUTCH DISEASE IN ISLAND TOURISM ECONOMIES}

The arguments put forward above and the statistics that have been described confirm the existence of island societies with a high degree of economic specialization and, at the same time, others that reflect greater diversification. This is an issue of major importance for tourism economies and it is the focus of crucial debate in economic policy making: that is, the pros and cons of tourism monocultures as opposed to a supposed inter-sectoral balance. It should be noted that little attention has been given in economic literature to an analysis of the long-term effects of specialization in tourism and where cases can be found, the conclusions do not coincide. There are authors who have found evidence that tourism contributes positively to the long-term growth of the economy (Balaguer-Cantavella, 2002, in the case of Spain), but others claim just the opposite (Ho, 2005, in the case of Corea). In a number of different studies a theoretical model known as «Dutch disease» was recently developed in order to analyse the effects of tourism specialization in the economies of the Balearics and the Canary Islands (Capó, 2003; Capó-Riera-Rosselló, 2005).

Dutch disease was a theoretical model originally developed by M. W. Corden-P. Neary (1982) and M. W. Corden (1984), aimed at analysing the productive reaction of an economy to growing exports of a commercializable good normally associated with the discovery of natural resources. The object of analysis is a small open economy comprising three sectors: one in the process of expansion (tourism in our case), another traditional one (manufacturing and agriculture) and a sector dealing in non-commercializable goods (services and construction). The sector in the process of expansion and the traditional one produce goods whose price is exogenously fixed on the international market. The prices of non-commercializable goods are determined at a domestic level and it is this market at which this production is directed. In the final outcome of the process, in addition to growing activity by the export sector linked to the exploitation of natural resources, two results should be highlighted (Capó, 2003). The first is the abandonment of the traditional sector by its workers, who are attracted to the new emerging sector given the higher wages that it offers. The consequence is shrinking production of traditional non-commercializable goods. Secondly, with the increase in real income that economic development brings, there is a growing internal demand for non-commercializable goods and, by extension, more incentive to produce them. As a result, an increase in the production of these goods is very likely to occur. Nonetheless, in addition to these factors, which play a guiding role in the area's economic growth, the Dutch disease model also points to inescapable negative repercussions (Capó-Riera-Rosselló, 2005):

- High sectoral dependence makes the area's internal economy highly vulnerable to external disturbances; 
- The composition of exports changes, since the service sector takes increasing precedence and the manufacturing sector, which is more closely related with technological development and research, becomes less relevant;

- On the labour market, most employees only need low qualifications, thus hindering the training of a more dynamic workforce;

- Tourism has a very big environmental impact, because hotel accommodation is mainly developed in coastal areas which are subject to seasonal pressure due to the rising population.

Bearing in mind the aforementioned environmental factors, let us now see if empirical evidence of Dutch disease can be found in the Mediterranean's IMEDOC islands, using precise elements:

1. Dependency on the emerging sector. Two basic formulae will be used. Firstly, the Coefficient of Specialization, which measures the degree of similarity between a region and its reference area. It is defined as follows:

$$
C S_{j}=\frac{1}{2} \sum_{i=1}^{h}\left|\frac{x_{i j}}{x_{j}}-\frac{x_{i}}{x}\right|
$$

where $\mathbf{X}_{\mathrm{ij}}$ is the GVA of the $\mathrm{i}$-th sector of region $\mathrm{j} ; \mathrm{X}_{\mathrm{j}}$ is the GVA of the $\mathrm{j}$-th region; $\mathbf{X}_{\mathrm{i}}$ is the GVA of the $i$-th sector of the reference area (the country as a whole); $x$ is the GVA of all the sectors of the reference area and $h$ represents the sectors under consideration. The result varies between 0 and 1 . If $\mathrm{CS}_{\mathrm{j}}=0$, region $\mathrm{j}$ has activities with the same composition as the reference area. The opposite occurs when $\mathrm{CS}_{\mathrm{j}}$ is close to a unit.

The results for the areas analysed in this study (shown in Tables 2, 3 and 4) show that the Balearics, Corsica, Sicily and, to a lesser extent, Sardinia, have the most widely differing productive structures from their respective states ${ }^{15}$. Doubtlessly being an island and the inherent costs that this implies both influence this situation (European Commission, 2003; Manera-Garau, 2005) ${ }^{16}$. However, their recent evolution indicates that the difference between the productive structures of the IMEDOC islands and that of their corresponding nation is greater when an island has seen a bigger rise in exports of tourist services, as confirmed by the figures for overnight stays. Thus of all France and Italy's regions, Sicily, Corsica and Sardinia are the ones that moved away the most from their corresponding nation's productive structure between 1995 and 2002. In contrast, the Balearics has seen a lower rise in overnight stays. That is, it has lessened the gap with the Spanish state.

15 Malta was not included in the estimations since it is a state and, as such, does not have a reference nation.

16 There are four different characteristics inherent in the «cost of insularity»: 1) Greater economic specialization. The islands have an economy that either specializes in the primary or tertiary sector. In none of them is the secondary sector dominant; 2) Considerable time and high costs in market access. A limited choice of transport, the saturation of these means of transport during the high season and goods transfer costs that are between two and four times higher than those of the continent hinder free market access to people, services and goods under the same conditions as the European continent; 3) Limited natural resources. The lack of energy, water and land conditions economic growth; 4) Less access to public services. Above all education (particularly university education and vocational training). This is one of the causes of the low level of training of the adult population. 
Table 2

SPANISH REGIONS \& THEIR COEFFICIENT

OF SPECIALIZATION, 1995 \& 2002

\begin{tabular}{|l|l|l|}
\hline & $\mathbf{1 9 9 5}$ & $\mathbf{2 0 0 2}$ \\
Andalusia & 0.113 & 0.103 \\
Aragón & 0.064 & 0.066 \\
Asturias & 0.090 & 0.074 \\
Balearic Islands & $\mathbf{0 . 2 2 9}$ & $\mathbf{0 . 2 0 5}$ \\
Canary Islands & 0.191 & 0.184 \\
Cantabria & 0.050 & 0.054 \\
Castilla-La Mancha & 0.114 & 0.090 \\
Castilla y León & 0.092 & 0.075 \\
Catalonia & 0.083 & 0.091 \\
Autonomous Community of Valencia & 0.059 & 0.049 \\
Extremadura & 0.191 & 0.193 \\
Galicia & 0.080 & 0.071 \\
Autonomous Community of Madrid & 0.114 & 0.124 \\
Murcia Region & 0.068 & 0.061 \\
Navarre & 0.138 & 0.149 \\
Basque Country & 0.113 & 0.113 \\
La Rioja & 0.144 & 0.153 \\
\hline
\end{tabular}

Source: Own based on Eurostat data.

Table 3

ITALIAN REGIONS \& THEIR COEFFICIENT

OF SPECIALIZATION, 1995 \& 2002

\begin{tabular}{|l|c|c|}
\hline & $\mathbf{1 9 9 5}$ & $\mathbf{2 0 0 2}$ \\
Abruzzo & 0.045 & 0.060 \\
Basilicata & 0.167 & 0.112 \\
Bolzano-Bozen & 0.192 & \\
Calabria & 0.109 & 0.158 \\
Campania & 0.079 & 0.097 \\
Emilia-Romagna & 0.042 & 0.082 \\
Friuili-Venezia Giulia & 0.162 & 0.144 \\
Lazio & 0.122 & 0.113 \\
Liguria & 0.110 & 0.103 \\
Lombardia & 0.062 & 0.071 \\
Marche & 0.131 & 0.095 \\
Molise & 0.073 & 0.063 \\
Piemonte & 0.112 & 0.108 \\
Puglia & $\mathbf{0 . 1 3 7}$ & $\mathbf{0 . 1 2 5}$ \\
Sardegna & $\mathbf{0 . 1 6 6}$ & $\mathbf{0 . 2 0 2}$ \\
Sicilia & 0.045 & 0.048 \\
Toscana & & \\
Trento & 0.036 & 0.035 \\
Umbria & 0.212 & 0.192 \\
Valle d'Aosta & 0.219 & 0.095 \\
Veneto & & \\
\hline
\end{tabular}

Source: Own based on Eurostat data.

Note: No data available for blank boxes. 
Table 4

FRENCH REGIONS \& THEIR COEFFICIENT

OF SPECIALIZATION, 1995 \& 2002

\begin{tabular}{|l|l|l|}
\hline & $\mathbf{1 9 9 5}$ & $\mathbf{2 0 0 2}$ \\
Alsace & 0.089 & 0.077 \\
Aquitaine & 0.092 & 0.076 \\
Auvergne & 0.098 & 0.102 \\
Basse-Normandie & 0.099 & 0.103 \\
Bourgogne & 0.090 & 0.104 \\
Bretagne & 0.098 & 0.100 \\
Centre & 0.087 & 0.084 \\
Champagne-Ardenne & 0.135 & 0.135 \\
Picardie & 0.133 & 0.110 \\
Corse & $\mathbf{0 . 1 7 6}$ & $\mathbf{0 . 2 0 7}$ \\
Dep.Fra.Ultramar & 0.203 & 0.191 \\
Franche-Comté & 0.160 & 0.151 \\
Haute-Normandie & 0.119 & 0.149 \\
Languedoc-Roussillon & 0.098 & 0.104 \\
Limousin & 0.083 & 0.090 \\
Lorraine & 0.100 & 0.136 \\
Midi-Pyrénées & 0.071 & 0.059 \\
Nord-Pas-de-Calais & 0.104 & 0.091 \\
Pays de la Loire & 0.082 & 0.103 \\
Poitou-Charentes & 0.073 & 0.090 \\
Provence-Alpes-Côte d'Azur & 0.092 & 0.075 \\
Rhône-Alpes & 0.067 & 0.068 \\
\hline
\end{tabular}

Source: Own based on Eurostat data.

To complete our calculations, the Number of Equivalent Sectors (NES) was estimated. This can be expressed as:

$$
N E S_{j}=\frac{1}{\sum_{i=1}^{h}\left(\frac{x_{i j}}{x_{j}}\right)^{2}}
$$

where $x_{i j}$ is the GVA of the $i$-th sector of region $j ; x_{j}$ is the GVA of the $j$-th region; and $\mathrm{h}$ are the sectors under consideration. The number of equivalent sectors varies from 1 to $\mathrm{h}$. If $\mathrm{NES}_{\mathrm{j}}=\mathrm{h}$, production is at its most diversified and the productive structure is equivalent to that of an economy with $\mathrm{h}$ sectors. The closer $\mathrm{NES}_{\mathrm{j}}$ is to a unit, the more the region specializes in a limited number of activities. 
An analysis of the available data shows that due to tourism the Balearics have a high degree of specialization in relation to the Spanish state, but Corsica, Sicily and Sardinia give differing results. In these last islands, where agriculture, fishing and mining or extraction activities play a more important role, the NES is higher ${ }^{17}$. Nonetheless, their recent evolution follows the same trend as above. While the Balearic archipelago has barely altered its level of economic diversification, Sardinia and Sicily are the Italian regions that have moved towards the highest specialization in a limited number of sectors. Meanwhile, Corsica has seen a slight rise in the level of diversification of its productive structure (see Tables 5, 6 and 7).

Table 5

NUMBER OF EQUIVALENT SECTORS. SPANISH REGIONS, 1995 \& 2002

\begin{tabular}{|l|c|c|}
\hline & $\mathbf{1 9 9 5}$ & $\mathbf{2 0 0 2}$ \\
Andalusia & 11.20 & 11.15 \\
Aragón & 9.56 & 9.69 \\
Asturias & 10.94 & 10.85 \\
Balearic Islands & $\mathbf{7 . 8 5}$ & $\mathbf{7 . 8 0}$ \\
Canary Islands & 9.92 & 9.46 \\
Cantabria & 9.86 & 9.78 \\
Castilla - La Mancha & 10.00 & 10.23 \\
Castilla y León & 11.03 & 10.92 \\
Catalonia & 7.88 & 8.13 \\
Autonomous Community of Valencia & 8.83 & 9.29 \\
Extremadura & 11.53 & 11.57 \\
Galicia & 11.51 & 11.11 \\
Autonomous Community of Madrid & 9.85 & 9.61 \\
Murcia Region & 10.35 & 10.39 \\
Navarre & 7.00 & 7.30 \\
Basque Country & 7.70 & 8.03 \\
La Rioja & 7.99 & 8.52 \\
Spain & 10.18 & 10.18 \\
\hline
\end{tabular}

Source: Own based on Eurostat data.

17 The NES has been estimated by the authors using available EUROSTAT figures for the GVA of European regions, broken down into 16 fields of activity. It should be remembered that NES results can be biased by the fact that the primary sector is divided into three fields of activity, the tertiary sector into ten and the secondary sector into just one. As a result, in the estimation of this NES, economies based on the primary or tertiary sector were regarded as being very highly diversified. 
Table 6

NUMBER OF EQUIVALENT SECTORS. ITALIAN REGIONS, 1995 \& 2002

\begin{tabular}{|l|c|c|}
\hline & $\mathbf{1 9 9 5}$ & $\mathbf{2 0 0 2}$ \\
Abruzzo & 8.41 & 8.54 \\
Basilicata & 9.76 & 8.73 \\
Bolzano-Bozen & & \\
Calabria & 9.76 & 9.49 \\
Campania & 9.46 & 8.93 \\
Emilia-Romagna & 7.00 & 7.26 \\
Friuili-Venezia Giulia & 8.18 & 8.07 \\
Lazio & 9.41 & 8.78 \\
Liguria & 8.99 & 8.20 \\
Lombardia & 6.29 & 6.63 \\
Marche & 7.48 & 7.60 \\
Molise & 9.73 & 8.81 \\
Piemonte & 6.61 & 7.04 \\
Puglia & 9.35 & 8.74 \\
Sardegna & $\mathbf{1 0 . 3 3}$ & $\mathbf{9 . 4 0}$ \\
Sicilia & $\mathbf{9 . 6 1}$ & $\mathbf{8 . 5 7}$ \\
Toscana & 7.88 & 7.97 \\
Trento & & \\
Umbria & 8.63 & 8.24 \\
Valle d'Aosta & 10.11 & 9.50 \\
Veneto & 6.72 & 7.09 \\
Italy & 8.25 & 8.19 \\
\hline
\end{tabular}

Source: Own based on Eurostat data.

Note: No data available for blank boxes.

An analysis of the composition of the GVA once again highlights the existence of two different growth models, as indicated earlier (see Table 8 and Manera-Garau, 2005):

a) The Balearics and Malta, with a well-consolidated tourist industry that is currently undergoing a sharp decline. In parallel, in the fifteen-member European Union the growth of the hotel and catering trade can be observed (accounting for a rising share of the GVA), together with a shrinking manufacturing sector (albeit by only half that of the islands' manufacturing sectors $)^{18}$. The construction industry is the only field of activity to have gained in importance in both economies, with a sharp rise in the case of the Balearics. The differences that can be detected between Malta and the Balearics

18 Outsourcing certain services formerly included in the structure of industry (tax and accountancy consultancy services, cleaning services, security etc.) has influenced industry's falling share of the GVA. These services, which were previously carried out by specific industrial departments, are now included in the field of activity «Real estate and business services». 
can be put down to the fact that the latter has placed particular emphasis on transport and trade, whereas Malta has preferred to prioritize sectors like education and health.

\section{Table 7}

\section{NUMBER OF EQUIVALENT SECTORS. FRENCH REGIONS, 1995 \& 2002}

\begin{tabular}{|l|l|l|}
\hline & $\mathbf{1 9 9 5}$ & $\mathbf{2 0 0 2}$ \\
Alsace & 7.97 & 6.73 \\
Aquitaine & 8.86 & 8.09 \\
Auvergne & 8.06 & 7.60 \\
Basse-Normandie & 8.37 & 8.03 \\
Bourgogne & 8.44 & 8.44 \\
Bretagne & 9.08 & 8.76 \\
Centre & 8.16 & 7.81 \\
Champagne-Ardenne & 8.21 & 8.17 \\
Picardie & 7.07 & 7.31 \\
Corse & $\mathbf{8 . 6 9}$ & $\mathbf{8 . 8 2}$ \\
Dep,Fra,Ultramar & 9.13 & 9.51 \\
Franche-Comté & 6.07 & 6.10 \\
Haute-Normandie & 7.13 & 6.50 \\
ille de France & 6.99 & 6.14 \\
Languedoc-Roussillon & 8.34 & 8.05 \\
Limousin & 9.12 & 8.77 \\
Lorraine & 7.97 & 6.73 \\
Midi-Pyrénées & 9.12 & 8.77 \\
Nord-Pas-de-Calais & 7.62 & 7.41 \\
Pays de la Loire & 8.36 & 7.80 \\
Poitou-Charentes & 9.21 & 8.94 \\
Provence-Alpes-Côte d'Azur & 8.01 & 7.96 \\
Rhône-Alpes & 7.17 & 6.83 \\
France & 8.16 & 7.62 \\
\hline
\end{tabular}

Source: Own based on Eurostat data.

b) Sardinia, Corsica and Sicily, which have specialized increasingly in tourism in recent years. The main characteristics to be highlighted are booming hotel and catering trades (which still account for only a low share of the GVA), a rise in business services and the waning importance of the construction sector and industry (with a decline similar to that of the rest of continental Europe).

In short, in Malta and the Balearics a declining industrial sector can be observed, together with a boom in non-commercializable goods, encouraged by the impetus of the emerging sector, with a drop in manufacturing twice that of the European Union and the remaining IMEDOC regions. 
Table 8

GVA BY ACTIVITIES IN THE IMEDOC REGIONS \& 15-MEMBER EU, 1995 \& 2002

\begin{tabular}{|l|cc|c|c|c|c|c|c|c|c|c|c|c|}
\hline & \multicolumn{2}{|c|}{ Balearics } & \multicolumn{2}{c|}{ Sardinia } & \multicolumn{2}{c|}{ Corsica } & \multicolumn{2}{c|}{ Malta } & \multicolumn{2}{|c|}{ Sicily } & \multicolumn{2}{|c|}{ EU15 } \\
\cline { 2 - 12 } & $\mathbf{1 9 9 5}$ & $\mathbf{2 0 0 2}$ & $\mathbf{1 9 9 5}$ & $\mathbf{2 0 0 2}$ & $\mathbf{1 9 9 5}$ & $\mathbf{2 0 0 2}$ & $\mathbf{1 9 9 5}$ & $\mathbf{2 0 0 2}$ & $\mathbf{1 9 9 5}$ & $\mathbf{2 0 0 2}$ & $\mathbf{1 9 9 5}$ & $\mathbf{2 0 0 2}$ \\
\cline { 2 - 11 } Agriculture, hunting & & & & & & & & & & & & \\
\& forestry & 1.7 & 1.4 & 4.4 & 3.8 & 3.0 & 2.2 & 2.1 & 2.2 & 5.1 & 3.7 & 2.6 & 1.9 \\
Fishing & 0.2 & 0.1 & 0.2 & 0.3 & 0.1 & 0.1 & 0.2 & 0.3 & 0.3 & 0.2 & 0.1 & 0.1 \\
Mining \& extraction & 0.1 & 0.1 & 0.5 & 0.5 & 0.2 & 0.2 & 0.3 & 0.4 & 0.3 & 0.2 & 0.8 & 0.9 \\
Industry & 6.5 & 5.2 & 12.0 & 10.0 & 3.7 & 3.6 & 23.6 & 19.2 & 9.3 & 8.6 & 20.7 & 18.5 \\
Electricity, gas and & & & & & & & & & & & & \\
hydroelectric energy & 3.5 & 2.1 & 2.8 & 3.3 & 4.1 & 3.7 & 2.0 & 1.1 & 2.8 & 2.8 & 2.5 & 1.9 \\
Construction & 6.7 & 8.8 & 8.1 & 6.5 & 7.4 & 6.5 & 3.9 & 4.6 & 6.6 & 6.1 & 5.8 & 5.5 \\
Commerce \& repairs & 9.1 & 10.1 & 12.9 & 13.5 & 11.1 & 11.2 & 11.5 & 11.5 & 13.2 & 5.7 & 11.5 & 11.4 \\
Hotel \& catering & 26.6 & 25.6 & 3.7 & 4.1 & 4.7 & 6.2 & 7.4 & 6.5 & 2.2 & 3.2 & 2.6 & 3.0 \\
Transport \& & & & & & & & & & & & & \\
construction & 10.6 & 12.0 & 7.5 & 6.8 & 8.3 & 8.1 & 10.6 & 9.3 & 7.1 & 8.2 & 6.8 & 7.1 \\
Financial services & 4.6 & 4.7 & 4.5 & 4.0 & 3.5 & 2.6 & 5.2 & 6.0 & 4.7 & 4.3 & 5.4 & 5.0 \\
Real estate \& & & & & & & & & & & & & \\
business services & 13.5 & 13.6 & 16.8 & 21.3 & 22.7 & 21.5 & 11.2 & 13.0 & 20.2 & 25.3 & 19.4 & 22.6 \\
Public & & & & & & & & & & & & \\
Administration, & & & & & & & & & & & & \\
Social Security & 5.0 & 4.7 & 9.0 & 8.9 & 14.2 & 15.4 & 6.8 & 7.9 & 10.0 & 10.6 & 6.8 & 6.3 \\
Education & 3.5 & 3.3 & 8.4 & 7.7 & 6.5 & 6.2 & 5.8 & 7.1 & 8.4 & 9.4 & 4.8 & 4.9 \\
Health \& Social & & & & & & & & & & & & \\
Services & 4.5 & 4.6 & 5.7 & 5.9 & 8.3 & 8.7 & 5.0 & 5.9 & 5.9 & 6.9 & 6.1 & 6.5 \\
Other social & & & & & & & & & & & & \\
activities & 3.0 & 3.0 & 2.8 & 2.9 & 1.9 & 2.9 & 4.2 & 4.8 & 3.1 & 4.1 & 3.6 & 3.9 \\
Household activities & 1.0 & 0.8 & 0.7 & 0.6 & 0.4 & 0.7 & 0.2 & 0.2 & 0.7 & 0.6 & 0.4 & 0.5 \\
\hline
\end{tabular}

Source: Own based on Eurostat data.

2. A lower level of research and technological development. The islands have a level of technological development below that of the EU average (calculated by estimating the percentage of the GDP dedicated to R\&D). This lack of financial investment into Regional Innovation Systems is also evident in applications for patents over the last few years (1999-2001), falling far behind the level of research and technological development in the islands' corresponding states and behind European levels. This sorry state of affairs might be attributable to the weaker role played by industry. Indeed, data for France, Spain and Italy show that processing and conversion activities (excluding building) and business services are fields of activity where a greater percentage of innovative firms can be found (European Commission, 2004). More specifically, 46\% of all manufacturing firms carry out R\&D activities in France, 38\% in Spain and 40\% in Italy. In the case of business services, the corresponding results are $41 \%, 33 \%$ and $36 \%$. Given the lower presence of both 
fields of activity in the IMEDOC islands (varying between $36 \%$ in Sardinia and $19 \%$ in the Balearics in comparison with the $41 \%$ EU average), the lower degree of research and technological development can partly be explained. However, this is not the only reason for such striking differences. Two other explanations can also be found:

- An organized network of small businesses. One characteristic that is common to European island regions is the high percentage of consortiums of this kind (European Commissions, 2003). The lower percentage of big companies can be attributed to factors like the reduced size of the islands' internal markets or the reticence of more powerful companies and multinationals to open up there (given the high transport costs and low level of training), and these types of companies are the most likely ones to carry out research and development activities (Eurostat, 2004).

- Insufficient public sector support. The public sector has made limited efforts to promote R\&D policies, only offset by the research work of their island universities, whose efforts come close to EU levels. However, in terms of government spending on $R \& D$, island levels are between two (Sardinia) and five (the Balearics) times less than the EU average.

3. The low level of training. In comparison with any other EU regional economy, the level of training in IMEDOC regions is low: among 60\% (the Balearics, Corsica, Sicily and Sardinia) and 70\% (Malta) of the population aged between 25 and 59 have a low level of training, below that of a student who has completed their secondary school studies. The EU average stands at $35 \%$. The said regions have invested considerable efforts into training, as proven by the greater weight given to education by their respective economies (with the only exception of the Balearics). Sardinia, Corsica and Sicily's recent past, where agriculture and fuel extraction played an important role, appears to have influenced the current situation. In the Balearics, the exploitation of natural resources for tourism purposes and the central role played by the construction industry seem to have influenced the creation of a labour market with a demand for unskilled workers ${ }^{19}$. In summary, these are activities with a low added value and, by extension, low productivity levels (MascaróNavinés, 2004; Navinés-Balagué-Bonnail-Franconetti, 2004).

Despite the above factors, one significant aspect which calls for specific research must also be taken into consideration: the degree of diversification of the said economies' tertiary sectors. In this respect, the undeniably useful Clarkian approach to the division of sectors must give way to a much richer (and much more useful, in the case of regional economies) vision based on the intrinsic composition of a service sector and its productive orientation. This would subtly alter the theory of signs of Dutch disease in the Maltese and Balearic economies (areas where the theoretical model can no doubt be best applied, as we have already seen) from the moment that specialization is no longer automatically regarded to be a negative characteristic of economies that have achieved a high level of income through mass tourism, in contrast with other surrounding regions. However, this

19 During the period 1964-1969, the Balearics held ninth place among those regions of Spain with the highest percentage of the population with higher education studies. By 2000-2001, the Balearics were third from last (out of a total of 17 regions). This only serves to confirm the arguments outlined in the article (data from the Spanish Institute for Statistics and Capó [2003]) 
reflection is merely intended to suggest the need for a more specific line of research aimed at ascertaining whether specialization in the service sector (particularly tourism) offers island economies solid guarantees of successful market competition (Rozenblat-Cicille, 2003; Navinés, 2005).

\section{CONCLUSIONS}

The Mediterranean, one of the world's leading tourist areas, has not remained unaffected by recent trends in the tourism market. Destinations other than the Mediterranean's traditional ones (France, Spain and Italy) have becoming increasingly popular in recent years, while the number of travellers from the Middle East and Southeast Asia has also risen. At the same time, tourism has come to play an increasing economic role in the generation of revenue and employment, even if its negative externalities (in terms of population congestion and the concentration of tourist accommodation) have also increased and spread along the entire Mediterranean shore.

Within this context, the Mediterranean's western islands account for a large part of tourism to the area. In conjunction, they are characterized by a high dependency on a limited number of issuing markets, a high degree of seasonality and evidence of significant environmental effects. The main differences that can be detected are the greater presence of foreign tourists in Malta and the Balearics and a clear dependency on the domestic market in the case of Sardinia, Corsica and Sicily. If the recent evolution of the said islands' tourism variables is analysed (islands with a falling market share due to the emergence of new destinations), two different models can be distinguished. Firstly, Malta and the Balearics, which have held pride of place among the IMEDOC islands for decades now, although they are currently showing signs of maturity in the sense described by R. W. Butler. Leaving aside the effects of temporary phenomena, both archipelagos show symptoms of a structural incapacity to attract tourists from new issuing markets. The drop in the number of overnight stays, shrinking tourist expenditure and the reduction in the average length of stay are all proof of this. The deterioration of the environment and difficulty in competing through prices both hinder the exportation of tourism services. On the other hand, Corsica, Sardinia and Sicily show lower levels of population congestion and overdevelopment than Malta and the Balearics. These three regions have been destinations in the process of expansion for more than fifteen years. This statement is supported by the big increase in overnight stays or the maintenance of the average length of stay. The fact that they are «newcomers» to tourism (in contrast, for example, with the Balearics' longer experience) explains why they have undergone a more vigorous, sustained process of expansion, echoing a process identified in the economic history of the industrial sector (Pollard, 1991; Sylla-Toniolo, 1991).

A tourism-related analysis of the islands points to the relevance of certain existing economic models. The model known as Dutch disease has been used to systematize the long-term negative effects of an economy's specialization in the exploitation of natural resources: tourism, in this case. However, these regions' island status and the associated costs of insularity also play a highly influential role in determining the consequences of specializing in tourism. In Malta and the Balearics, high dependency on the tourist industry 
has drained productive resources from the manufacturing and traditional sectors (Manera, 2001), with a growth in the importance of services and non-commercializable goods like construction. In Sardinia, Corsica and Sicily, economies where tourism plays a lesser role, a similar process is now in the early stages, directed at more intensive specialization in tourism.

Tourism is unquestionably a fantastic growth opportunity for the Mediterranean, particularly for less developed countries. This is also true for islands that have not taken full advantage of their tourism potential. In the long term, specialization in a limited number of sectors need not generate negative effects (as demonstrated by the fact that France, Spain and Italy's most developed regions are those with the most highly specialized economic structures). However it should not be forgotten that almost exclusive dedication to tourism generates high negative externalities, as we have seen. What is more, with forecasts of an anticipated $2 \%$ moderate yearly growth in the number of international leisure or holiday travellers and a context in which there are fully consolidated emerging destinations well able to compete in more than just price terms, competition in the Mediterranean is expected to hot up. As a result, over the next few years there may be a process of adjustment, particularly in coastal areas that specialize heavily in tourism. The lesson that Mediterranean island economies must learn from the cases of Malta and the Balearics is that special attention must be given to the environment, without overlooking all the other factors that determine the quality of a tourism product, such as skilled labour and the development of a Regional Innovation System: a basic tool in the training of human capital and, by extension, in guaranteeing optimum productivity and competitive capacity.

\section{BIBLIOGRAPHY}

AGENDA LOCAL 21 (1999): Calvià Town Council (Mallorca).

AGUILÓ, E.-ALEGRE, J.-CLADERA, M.-SARD, M (2002): «La fase de post-estancamiento de un destino turístico maduro. Dressing up to Screen the Same Blowsy Tart?», Fitur Award, Madrid.

AGUILÓ, E.-ALEGRE, J.-SARD, M. (2003): «The Persistence of Sun and Sand Tourism Model», in Tourism Management, issue 26.

ALCAIDE, J. (2003), Evolución económica de las regiones y provincias españolas en el siglo $X X$, BBVA Foundation (Bilbao).

ALCOVER, A., et alter (2001): «El grau de competitivitat de l'economia balear», Conjuntura 2015, issue 1, Centre for Economic Research, Sa Nostra-UIB.

ALEGRE, J.-POU, LL. (2002): «The Determinants of the Probability of Tourism Consumption: an Analysis with a Family Expenditure Survey», in Working Papers, 39, Department of Applied Economics, University of the Balearic Islands.

ALEGRE, J.-POU, LL. (2003a): «La reducción del tiempo de estancia en los destinos vacacionales: implicaciones sobre el gasto turístico y la estacionalidad en las Islas Baleares», in G. LÓPEZ CASASNOVAS (Dir.), Islas Baleares. Serie Estudios Regionales, BBVA Foundation (Madrid). 
ALEGRE, J.-POU, LL. (2003b). «El turismo de sol y playa desde la perspectiva de los consumidores europeos. Un nuevo desafío en el desarrollo turístico de Baleares»,ien G. LÓPEZ CASASNOVAS (Dir.), Islas Baleares. Serie Estudios Regionales, BBVA Foundation (Madrid).

ANISI, D. (2005): «La macroeconomía al comienzo del siglo XXI: una reflexión sobre el uso y posterior abandono del llamado keynesianismo», Estudios de Economía Política, issue 1.

APOSTOLOPOULOS, Y.-LOUKISSAS, P.-LEONTIDOU, L. (2001): Mediterranean

Tourism. Facets of Socioeconomic Development and Cultural Change, Routledge (London).

AYMARD, M. (1987): «Economia e società: uno sguardo d'insieme», in M. AYMARD-G. GIARRIZZO, Storia d'Italia. Le regioni dall'Unita a oggi. La Sicilia, Giulio Einaudi editore (Torino).

AZAR, C. et alter (1996): «Socio-Ecological Indicators for Sustainability», Ecological Economics, 18.

BALAGUER, J.-CANTAVELLA, M. (2002): «Tourism as a Long-Run Economic Growth Factor: the Spanish Case», Applied Economics, 34.

BLÁZQUEZ, M.-MURRAY, I.-GARAU, J.M. (2002): El tercer boom. Indicadors de sostenibilitat del turisme de les Illes Balears, 1989-1999, Centre d'Investigació i Tecnologies Turístiques de les Illes Balears (Palma).

BUCKLEY, P.J.-BROOKE, M. (1988): «Foreign Investment», in Handbook of Internactional Trade, Macmillan (Basingstoke).

BUTERA, S.-CIACCIO, G. (2002): Aspetti e tendenze dell'economia siciliana, Il Mulino (Milán).

BUTLER, R.W. (1980): «The Concept of a Tourist Area Cycle of Evolution: Implications for the Management of Resources», Canadian Geographer, 24 (1).

CANCILA, O. (1995), Storia dell'industria in Sicilia, Laterza (Bari).

CANNARI, L.-CHIRI, S. (2000): Lo sviluppo economico della Sardegna, Il Mulino (Milan).

CAPÓ, J. (2003), «Especialización productiva: una nota sobre la enfermedad balear», in G. LÓPEZ CASASNOVAS (Dir.): Islas Baleares. Serie Estudios Regionales, BBVA Foundation (Madrid).

CAPÓ, J.-RIERA, A.-ROSSELlÓ, J. (2005): «Dutch Disease in Tourism Economies. Evidence from Spain», in Documents de Treball del Centre for Economic Research, UIB-Sa Nostra, www.cre.uib.es.

EUROPEAN COMMISSION (1998): «Facts and Figures on the Europeans on Holiday, 1997-1998». Directorate General XXII

EUROPEAN COMMISSION (2003): Analysis of the Island Regions and Outermost Regions of the European Union: The Island regions and Territories, http://europa. eu.int/comm/regional_policy/index_en.htm

EUROPEAN COMMISSION (2004): INNOVAT. Survey on Innovation in EU Enterprises.2004, http://epp.eurostat.cec.eu.int/portal/page?_pag eid=1090,30070682,1090_30298591\&_dad=portal\&_schema=PORTAL

CORDEN, M.W. (1984): «Booming Sector and Dutch Disease Economies: Survey and Consolidation», Oxford Economic Papers, issue 36. 
CORDEN, M.W.-NEARY, P. (1982): «Booming Sector and De-Industrialization in a Small Open Economy», The Economic Journal, issue 92.

EASTERLY, W. (2003): En busca del crecimiento, Antoni Bosch editor (Barcelona).

FERNÁNDEZ FUSTER, L. (1991): Geografía general del turismo de masas, Alianza (Madrid).

HANLEY, N. et alter (1999): «Measuring Sustainability: A Time Series of Alternative Indicators for Scotland», Ecological Economics, 28.

EUROSTAT (several years), «General and Regional Statistics», http://epp.eurostat. cec.eu.int/portal/page?_pageid=1090,30070682,1090_30298591\&_dad=portal\&_ schema=PORTAL

IOANNIDES, D.-DEBAGGE, K. (Eds.) (1998): The Economic Geography of the Tourist Industry, Routledge (London).

JACOBS, M. (1996): La economía verde. Medio ambiente, desarrollo sostenible y la política del futuro, Icaria (Madrid).

KALDOR, N. (1967): Strategic Factors in Economic Development, Cornell University (New York).

KNICKERBOCKER; F. (1973): Oligopolistic reaction and multinational enterprises, Division of Research Graduate School of Business Administration (Boston).

MADDISON, A. (1995): Monitoring the world economy, OECD (Paris).

MADDISON, A. (1997): «The Nature and Functioning of European Capitalism: A Historical and Comparative Perspective», Banca Nationale del Lavoro Quarterly Review, December.

MADDISON, A. (2003): The world economy: Historical Statistics, OECD (Paris).

MANERA, C. (2001): Història del creixement econòmic a Mallorca, 1700-2000, Lleonard Muntaner editor (Palma).

MANERA, C.-GARAU, J. (2005): «Los costes de la insularidad en el desarrollo económico. Un contraste en el Mediterráneo occidental», Mediterráneo Económico, issue 7.

MANERA, C.-RIERA, A. (2001): «Per una planificació integral de l'economia balear», in C. MANERA (Dir.), Història ecològica a les Balears. Estudis sobre energia, economia $i$ medi ambient, Lleonard Muntaner Editor (Palma).

MASCARÓ, P.-NAVINÉS, F. (2004): «Turisme i territori, elements claus per explicar la competitivitat i la productivitat a les Illes Balears», in DIFFERNT AUTHORS, Comportament de la productivitat i la competitivitat a les Illes Balears, Consell Econòmic i Social (Palma).

MORLEY, C.L. (1992): «A Microeconomic Theory of International Tourism Demand», Annals of Tourism Research, issue 19.

NAVINÉS, F. (2005): «Algunes reflexions fetes des de l'enfocament clàssic de l'excedent sobre el procés de terciarització i especialització productiva: el cas de Balears», working paper, unpublished.

NAVINÉS, F.-BALAGUÉ, J.-BONNAIL, M.-FRANCONETTU, J, (2004): «Anàlisi de la dinàmica competitiva: el cas de Balears (1955-1995)», in DIFFERENT AUTHORS, Comportament de la productivitat $i$ la competitivitat a les Illes Balears, Consell Econòmic i Social (Palma).

OECD (1991): Environmental Indicators: A Preliminary Set (Paris). 
WTO (2003): Tourism Highlightss. Edition 2003, www.world-tourism.org

WTO (2004): Compendium of Tourism Statistics. Data 1998-2002, World Tourism Organization (Madrid).

WTO (2004): Tourism Market Trends, www.world-tourism.org

WTO (several years): Yearbook of Tourism Statistics, World Tourism Organization (Madrid).

WTO (several years): Compendium of Tourism Statistics, World Tourism Organization (Madrid).

ORTU, G. (1998): «Tra Piemonte e Italia. La Sardegna in età liberale (1848-1896)», in

L. BERLINGUER-A. MATTONE, Storia d'Italia. Le regioni dall'Unita a oggi. La Sardegna, Giulio Einaudi editore (Torino).

PACI, R. (1997): Crescita economica e Sistemi Produttivi Locali in Sardegna, C.U.E.C. (Cagliari).

PAPATHEODOROU, A.-SONG, H. (2005): «International Tourism Forecasts: TimeSeries Analysis of World and Regional Data», Tourism Economics, 11 (1).

POLLARD, S. (1991): La conquista pacífica, Prensas Universitarias de Zaragoza (Zaragoza).

POON, A. (1993): Tourism, Technology and Competitive Strategies, CAB International (Wallingford).

RAMÓN, A. (2002): La expansión internacional del sector hotelero español, Caja de Ahorros del Mediterráneo (Valencia).

RAVIS-GIORDANI, G. (2004): Atlas ethnohistorique de la Corse, Editions du Comité des travaux historiques et scientifiques (Paris)

REIG, E.-PICAZO, A. (1998): Capitalización y crecimiento de la economía balear, 1955 1996, BBVA Foundation (Bilbao).

RIERA, A. (1999): «Mass Tourism and the Demand for Protected Natural Areas: A travel Cost Approach», Journal of Environmental Economics and Management, 39.

ROMER, P. (1986): «Increasing Returns and Long-Run Growth», Journal of Political Economy, 94.

ROSSELLÓ, J. (2003), «Evolución y perspectivas de la demanda turística en Baleares», in G. LÓPEZ CASASNOVAS (Dir.), Islas Baleares. Serie Estudios Regionales, BBVA Foundation (Madrid)

ROZENBLAT, C.-CICILLE, P. (2004): Les villes européennes. Analyse comparative, Maison de la Géographie (Montpelier).

RUJU, S. (1998): «Società, economia, politica dal secondo dopoguerra a oggi (19441998), in L. BERLINGUER-A. MATTONE, Storia d'Italia. Le regioni dall'Unita a oggi. La Sardegna, Giulio Einaudi editore (Torino).

SYLLA, R.-TONIOLO, G. (Eds.), (1991), Patterns of European Industrialization: the XIX Century, Routledge (London).

VAN DER BERGH, J.-VERBRUGGEN, H (1999): «Spatial Sustainability, Trade and Indicators: An Evaluation of the Ecological Footprint», Ecological Economics, 29.

VELLAS, F., (2004): Economía y política del turismo internacional, Síntesis (Madrid). 


\section{APPENDIXES}

\section{Appendix 1 \\ INTERNATIONAL TOURIST ARRIVALS TO MEDITERRANEAN COUNTRIES, 1990-2002}

\begin{tabular}{|c|c|c|c|c|c|c|c|c|c|c|c|c|c|}
\hline & 1990 & 1991 & 1992 & 1993 & 1994 & 1995 & 1996 & 1997 & 1998 & 1999 & 2000 & 2001 & 2002 \\
\hline Albania & & & 28 & 45 & 28 & 40 & 56 & 19 & 28 & 26 & 32 & 34 & 34 \\
\hline Algeria & 137 & 1,193 & 1,120 & 1,128 & 805 & 520 & 605 & 635 & 678 & 749 & 866 & 901 & 988 \\
\hline Bosnia-Herz. & & & 1 & 3 & 6 & 37 & 99 & 76 & 148 & 89 & 171 & 139 & 160 \\
\hline Croatia & & & 1,271 & 1,521 & 2,293 & 1,324 & 2,649 & 4,178 & 4,499 & 3,805 & 5,831 & 6,544 & 6,944 \\
\hline Cyprus & 1,561 & 1,385 & 1,991 & 1,841 & 2,069 & 2,100 & 1,950 & 2,088 & 2,223 & 2,434 & 2,686 & 2,697 & 2,418 \\
\hline Egypt & 2,411 & 2,112 & 2,944 & 2,291 & 2,356 & 2,871 & 3,528 & 3,656 & 3,213 & 4,490 & 5,116 & 4,357 & 4,906 \\
\hline Slovenia & & & 616 & 624 & 748 & 732 & 832 & 974 & 977 & 884 & 1,090 & 1,219 & 1302 \\
\hline Spain & 34,300 & 35,347 & 36,492 & 37,268 & 43,232 & 38,803 & 40,541 & 39,553 & 43,396 & 46,776 & 47,898 & 50,094 & 52,327 \\
\hline France & 52,497 & 54,822 & 59,740 & 60,565 & 61,312 & 60,033 & 62,406 & 67,310 & 70,109 & 73,147 & 77,190 & 75,202 & 77,012 \\
\hline Greece & 8,873 & 8,036 & 9,331 & 9,413 & 10,713 & 10,130 & 9,233 & 10,070 & 10,916 & 12,164 & 13,096 & 14,057 & 14,180 \\
\hline Israel & 1,063 & 943 & 1,609 & 1,656 & 1,839 & 2,215 & 2,100 & 2,010 & 1,942 & 2,312 & 2,417 & 1,196 & 862 \\
\hline Italy & 26,679 & 26,840 & 26,113 & 26,379 & 27,480 & 31,052 & 32,943 & 34,692 & 34,933 & 36,516 & 41,522 & 39,563 & 39,799 \\
\hline Lebanon & & & 210 & 311 & 380 & 450 & 424 & 558 & 631 & 673 & 742 & 837 & 956 \\
\hline Libya & 96 & 90 & 89 & 63 & 52 & 56 & 88 & 50 & 32 & 178 & 174 & 169 & 135 \\
\hline Macedonia & & & 219 & 208 & 185 & 147 & 136 & 121 & 157 & 181 & 224 & 99 & 123 \\
\hline Malta & 872 & 895 & 1,002 & 1,063 & 1,176 & 1,116 & 1,054 & 1,111 & 1,182 & 1,214 & 1,216 & 1,180 & 1,134 \\
\hline Morocco & 4,024 & 4,162 & 4,390 & 4,027 & 3,465 & 2,602 & 2,693 & 3,072 & 3,095 & 3,817 & 4,240 & 4,342 & 4,303 \\
\hline Monaco & 245 & 239 & 246 & 208 & 217 & 233 & 226 & 259 & 278 & 278 & 300 & 270 & 263 \\
\hline Syria & 562 & 622 & 684 & 703 & 718 & 815 & 830 & 891 & 1,267 & 1,386 & 1,416 & 1,318 & 1,658 \\
\hline Serbia-Mont. & & & 156 & 77 & 246 & 228 & 301 & 298 & 283 & 152 & 239 & 351 & 448 \\
\hline Tunisia & 3,204 & 3,224 & 3,540 & 3,656 & 3,856 & 4,120 & 3,885 & 4,263 & 4,718 & 4,832 & 5,058 & 5,387 & 5,064 \\
\hline Turkey & 4,799 & 5,158 & 6,549 & 5,904 & 6,034 & 7,083 & 7,966 & 9,040 & 8,960 & 6,893 & 9,586 & 10,783 & 12,790 \\
\hline Yugoslavia & 7,880 & 1,459 & & & & & & & & & & & \\
\hline TOTAL & 150,203 & 146,527 & 158,341 & 158,954 & 169,210 & 166,707 & 174,545 & 184,924 & 193,665 & 202,996 & 221,110 & 220,739 & 227,806 \\
\hline
\end{tabular}

Source: Own based on WTO data.

Note: Data in thousands. No data available for blank boxes. Data for Yugoslavia is shown until 1991. From 1992 onwards it is shown for Bosnia- Herzegovina, Croatia, Slovenia, Macedonia \& Serbia-Montenegro. 
Appendix 2

OVERNIGHT STAYS BY TOURISTS IN MEDITERRANEAN COUNTRIES, 1990-2002

\begin{tabular}{|c|c|c|c|c|c|c|c|c|c|c|c|c|c|}
\hline & 1990 & 1991 & 1992 & 1993 & 1994 & 1995 & 1996 & 1997 & 1998 & 1999 & 2000 & 2001 & 2002 \\
\hline Albania & & & 77 & 132 & 68 & 89 & 144 & 71 & 73 & 96 & 98 & 91 & 91 \\
\hline Algeria & 650 & 669 & 358 & 364 & 347 & 364 & 354 & 85 & 133 & 159 & 125 & 284 & 447 \\
\hline \multicolumn{2}{|l|}{ Bosnia-Herz. } & & & & & & & 212 & 355 & 214 & 389 & 330 & 392 \\
\hline Cyprus & 9,426 & 8,275 & 13,232 & 12,256 & 14,322 & 14,222 & 12,702 & 13,193 & 14,456 & 16,126 & 16,816 & 18,093 & 15,289 \\
\hline Croatia & & & 7,555 & 9,758 & 15,556 & 8,515 & 16,546 & 25,114 & 26,545 & 21,885 & 34,045 & 38,384 & 39,711 \\
\hline Egypt & 19,943 & 16,231 & 21,836 & 15,089 & 15,433 & 20,451 & 23,765 & 26,579 & 20,151 & 31,002 & 32,788 & 29,813 & 32,664 \\
\hline Slovenia & & & 2,015 & 2,012 & 2,373 & 2,322 & 2,437 & 2,945 & 2,934 & 2,627 & 3,277 & 3,653 & 3,847 \\
\hline Spain & 68,630 & 77,128 & 81,183 & 88,395 & 104,156 & 107,787 & 106,658 & 113,270 & 122,486 & 160,424 & 233,897 & 232,035 & 220,707 \\
\hline France & 363,809 & 372,175 & 426,500 & 434,665 & 505,533 & 490,877 & 459,524 & 497,480 & 518,142 & 550,018 & 585,443 & 581,037 & 588,430 \\
\hline Greece & 35,012 & 29,873 & 36,260 & 36,475 & 40,658 & 38,772 & 36,118 & 39,992 & 42,565 & 45,803 & 46,636 & 46,574 & 46,574 \\
\hline Israel & 6,167 & 4,663 & 8,099 & 8,517 & 9,018 & 10,084 & 9,847 & 9,248 & 9,385 & 9,598 & 10,352 & 4,637 & 4,637 \\
\hline Italy & 84,720 & 86,735 & 83,643 & 85,431 & 101,005 & 113,001 & 118,024 & 118,360 & 121,242 & 126,668 & 140,357 & 146,672 & 145,560 \\
\hline Lebanon & & & & & & & & & & 215 & 692 & 610 & 653 \\
\hline Libya & & & & & & & 743 & 422 & 269 & 339 & 582 & 571 & 453 \\
\hline Macedonia & & & 382 & 363 & 336 & 276 & 277 & 266 & 2,067 & 1,839 & 1,941 & 1,042 & 1,576 \\
\hline Malta & 9,604 & 9,634 & 12,015 & 11,553 & 11,951 & 10,919 & 10,665 & 11,187 & 11,326 & 11,658 & 10,266 & 11,067 & 10,599 \\
\hline Morocco & 18,800 & 13,400 & 19,100 & 20,343 & 20,177 & 18,436 & 18,719 & 19,676 & 21,021 & 22,486 & 21,152 & 20,349 & 18,478 \\
\hline Monaco & 726 & 678 & 689 & 601 & 602 & 626 & 643 & 782 & 829 & 814 & 861 & 798 & 765 \\
\hline Syria & 1,706 & 1,715 & 3,923 & 3,303 & 2,977 & 3,160 & 3,098 & 2,961 & 4,454 & 5,130 & 5,997 & 5,997 & 6,297 \\
\hline \multicolumn{3}{|l|}{ Serbia- Mont. } & 393 & 209 & 831 & 805 & 1,099 & 1,001 & 990 & 498 & 865 & 1,281 & 1,650 \\
\hline Tunisia & 18,841 & 12,443 & 20,206 & 22,119 & 24,681 & 23,514 & 24,130 & 27,684 & 28,788 & 33,151 & 33,168 & 33,006 & 25,897 \\
\hline Turkey & 13,271 & 9,699 & 16,785 & 17,064 & 16,254 & 18,477 & 25,548 & 36,167 & 30,433 & 20,435 & 28,511 & 36,368 & 43,312 \\
\hline Yugoslavia & 43,370 & 5,600 & & & & & & & & & & & \\
\hline TOTAL & 694,675 & 648,918 & 754,251 & 768,649 & 886,278 & 882,697 & 871,041 & 946,095 & 978,644 & 1061185 & 1208258 & 1212692 & 1208029 \\
\hline
\end{tabular}

Source: Own based on WTO data.

Note: Data in thousands. No data available for blank boxes. Data for Yugoslavia is shown until 1991. From 1992 the data is for Bosnia-Herzegovina, Croatia, Slovenia, Macedonia \& Serbia-Montenegro. 


\section{Appendix 3}

NUMBER OF HOTEL BEDS OR BEDS IN SIMILAR ACCOMMODATION ESTABLISHMENTS, 1990-2002

\begin{tabular}{|c|c|c|c|c|c|c|c|c|c|c|c|c|c|}
\hline & 1990 & 1991 & 1992 & 1993 & 1994 & 1995 & 1996 & 1997 & 1998 & 1999 & 2000 & 2001 & 2002 \\
\hline Albania & 0 & 0 & 6 & 3 & 5 & 6 & 8 & 7 & 3 & 4 & 6 & 8 & 8 \\
\hline Algeria & 54 & 55 & 56 & 57 & 60 & 64 & 65 & 66 & 58 & 67 & 67 & 67 & 73 \\
\hline Bosnia-He. & 0 & 0 & 0 & 0 & 0 & 2 & 3 & 0 & 6 & 8 & 9 & 9 & 9 \\
\hline Croatia & 0 & 0 & 194 & 203 & 204 & 206 & 201 & 199 & 200 & 194 & 199 & 182 & 188 \\
\hline Cyprus & 52 & 57 & 63 & 67 & 70 & 73 & 74 & 83 & 85 & 84 & 84 & 88 & 90 \\
\hline Egypt & 84 & 106 & 110 & 117 & 121 & 129 & 141 & 151 & 167 & 187 & 23 & 241 & 264 \\
\hline Slovenia & 0 & 0 & 34 & 35 & 36 & 34 & 36 & 34 & 34 & 32 & 34 & 30 & 31 \\
\hline Spain & 1,102 & 1,146 & 999 & 1,092 & 1,132 & 1,074 & 1,088 & 1,102 & 1,121 & 1,282 & 1,314 & 1,337 & 1,395 \\
\hline France & 1,088 & 1,095 & 1,198 & 1,178 & 1,135 & 1,193 & 1,223 & 1,202 & 1,174 & 1,167 & 1,178 & 1,201 & 1,207 \\
\hline Greece & 438 & 459 & 476 & 486 & 509 & 536 & 549 & 561 & 577 & 585 & 592 & 601 & 606 \\
\hline Israel & 65 & 60 & 68 & 66 & 72 & 75 & 81 & 86 & 90 & 116 & 107 & 114 & 115 \\
\hline Italy & 1,704 & 1,708 & 1,723 & 1,725 & 1,724 & 1,738 & 1,765 & 1,772 & 1,782 & 1,807 & 1,854 & 1,891 & 1,930 \\
\hline Lebanon & 0 & 0 & 0 & 0 & 14 & 16 & 0 & 15 & 18 & 25 & 25 & 27 & 30 \\
\hline Libya & 9 & 0 & 18 & 15 & 16 & 0 & 0 & 0 & 0 & 0 & 20 & 21 & 21 \\
\hline Macedonia & 0 & 0 & 0 & 14 & 15 & 15 & 15 & 15 & 16 & 16 & 16 & 16 & 16 \\
\hline Malta & 42 & 41 & 36 & 36 & 38 & 37 & 38 & 39 & 39 & 41 & 41 & 41 & 41 \\
\hline Morocco & 111 & 116 & 120 & 116 & 117 & 123 & 124 & 123 & 125 & 128 & 128 & 130 & 138 \\
\hline Monaco & 0 & 0 & 0 & 0 & 0 & 2 & 2 & 2 & 2 & 2 & 2 & 2 & 2 \\
\hline Syria & 29 & 30 & 30 & 30 & 31 & 31 & 31 & 31 & 32 & 33 & 34 & 35 & 35 \\
\hline Serbia-M. & 0 & 0 & 83 & 84 & 85 & 86 & 86 & 86 & 81 & 77 & 79 & 80 & 80 \\
\hline Tunisia & 117 & 123 & 136 & 144 & 153 & 161 & 170 & 178 & 185 & 192 & 197 & 206 & 214 \\
\hline Turkey & 165 & 192 & 213 & 229 & 259 & 274 & 295 & 313 & 314 & 316 & 322 & 367 & 408 \\
\hline Yugoslavia & 364 & 361 & 0 & 0 & 0 & 0 & 0 & 0 & 0 & 0 & 0 & 0 & 0 \\
\hline TOTAL & 5,426 & 5,550 & 5,564 & 5,699 & 5,794 & 5,877 & 5,994 & 6,067 & 6,108 & 6,363 & 6,332 & 6,694 & 6,902 \\
\hline
\end{tabular}

Source: Own based on WTO data.

Note: Data in thousands. No data available for blank boxes. Data for Yugoslavia is shown until 1991. From 1992 it is shown for Bosnia-Herzegovina, Croatia, Slovenia, Macedonia \& Serbia-Montenegro. 


\section{Appendix 4}

TOURIST ARRIVALS TO IMEDOC REGIONS, 1990-2002

\begin{tabular}{|l|c|c|c|c|c|c|c|c|c|c|c|c|c|}
\hline & $\mathbf{1 9 9 0}$ & $\mathbf{1 9 9 1}$ & $\mathbf{1 9 9 2}$ & $\mathbf{1 9 9 3}$ & $\mathbf{1 9 9 4}$ & $\mathbf{1 9 9 5}$ & $\mathbf{1 9 9 6}$ & $\mathbf{1 9 9 7}$ & $\mathbf{1 9 9 8}$ & $\mathbf{1 9 9 9}$ & $\mathbf{2 0 0 0}$ & $\mathbf{2 0 0 1}$ & $\mathbf{2 0 0 2}$ \\
\hline Balearics & 6,349 & 6,518 & 6,660 & $\mathbf{7 , 1 3 1}$ & 8,250 & 8,468 & 8,586 & 9,280 & 10,067 & 10,820 & 10,800 & 10,143 & 9,623 \\
\hline Sardinia & 1,302 & 1,351 & 1,339 & 1,249 & 1,324 & 1,383 & 1,435 & 1,536 & 1,589 & 1,685 & 1,722 & 1,811 & 1,897 \\
\hline Corsica & 1,042 & 951 & 1,148 & 1,608 & 1,405 & 1,508 & 1,508 & 1,258 & 1,538 & 1,878 & 1,832 & 2,026 & 2,005 \\
\hline Malta & 872 & 895 & 1,002 & 1,063 & 1,176 & 1,116 & 1,054 & 1,111 & 1,182 & 1,214 & 1,216 & 1,180 & 1,134 \\
\hline Sicily & 2,733 & 2,772 & 2,476 & 2,376 & 2,750 & 2,917 & 3,188 & 3,220 & 3,424 & 3,611 & 3,958 & 4,069 & 4,029 \\
\hline IMED0C & 12,298 & 12,487 & 12,625 & 13,427 & 14,905 & 15,392 & 15,772 & 16,405 & 17,800 & 19,207 & 19,528 & 19,229 & 18,688 \\
\hline
\end{tabular}

Source: Own based on Manera-Riera (2001) for the Balearics Islands for 1990-2000 and on IBAE for 2001-2002, Eurostat for Corsica, Sardinia and Sicily, and the WTO for Malta. Data in thousands.

\section{Appendix 5}

\section{OVERNIGHT TOURIST STAYS IN IMEDOC REGIONS, 1990-2002}

\begin{tabular}{|l|c|c|c|c|c|c|c|c|c|c|c|c|c|}
\hline & 1990 & 1991 & 1992 & 1993 & 1994 & 1995 & 1996 & 1997 & 1998 & 1999 & $\mathbf{2 0 0 0}$ & $\mathbf{2 0 0 1}$ & $\mathbf{2 0 0 2}$ \\
\hline Balearics & 34,600 & 37,692 & 40,139 & 43,232 & 47,113 & 46,883 & 43,386 & 44,274 & 46,349 & 54,460 & 53,428 & 53,565 & 47,335 \\
\hline Sardinia & 6,854 & 6,988 & 6,815 & 6,476 & 6,941 & 7,404 & 7,550 & 8,117 & 8,369 & 9,115 & 9,476 & 10,240 & 10,215 \\
\hline Corsica & 3,426 & 3,430 & 3,543 & 4,963 & 4,286 & 3,926 & 3,170 & 3,504 & 4,293 & 5,734 & 5,883 & 6,668 & 6,638 \\
\hline Malta & 9,604 & 9,634 & 12,015 & 11,553 & 11,951 & 10,919 & 10,665 & 11,187 & 11,326 & 11,658 & 10,266 & 11,067 & 10,599 \\
\hline Sicily & 9,257 & 9,479 & 8,112 & 7,750 & 8,908 & 9,370 & 10,069 & 10,292 & 11,140 & 11,959 & 13,410 & 13,730 & 13,147 \\
\hline IMED0C & 63,741 & 67,224 & 70,625 & 73,973 & 79,199 & 78,503 & 74,840 & 77,374 & 81,477 & 92,925 & 92,463 & 95,270 & 87,934 \\
\hline
\end{tabular}

Source: Own based on Eurostat data for 1990-1998. The data for 1993-1998 does not include overnight stays by residents and non-residents in non-hotel group accommodation establishments or similar. For 1999-2002, data is taken from the IBAE for the Balearics, Eurostat for Corsica, Sardinia and Sicily and the WTO for Malta. Data in thousands.

\section{Appendix 6 \\ NUMBER OF BEDS IN HOTELS \& SIMILAR ACCOMMODATION ESTABLISHMENTS, CAMP SITES, HOLIDAY APARTMENTS AND OTHER TYPES OF GROUP ACCOMMODATION IN IMEDOC REGIONS, 1990-2002}

\begin{tabular}{|l|c|c|c|c|c|c|c|c|c|c|c|c|c|}
\hline & 1990 & 1991 & 1992 & 1993 & 1994 & 1995 & 1996 & 1997 & 1998 & 1999 & $\mathbf{2 0 0 0}$ & $\mathbf{2 0 0 1}$ & $\mathbf{2 0 0 2}$ \\
\hline Balearics & 386,918 & 388,999 & 389,449 & 380,796 & 382,815 & 384,953 & 388,510 & 394,473 & 398,805 & 406,876 & 411,129 & 414,120 & 415,264 \\
\hline Sardinia & 108,455 & 115,932 & 118,944 & 120,006 & 122,466 & 127,653 & 132,609 & 134,466 & 137,677 & 140,106 & 147,229 & 150,842 & 158,042 \\
\hline Corsica & 108,533 & 108,533 & 101,619 & 200,832 & 122,942 & 114,568 & 114,568 & 93,469 & 92,988 & 101,355 & 105,884 & 108,196 & 108,069 \\
\hline Malta & 42,291 & 40,894 & 36,367 & 36,388 & 37,795 & 37,308 & 38,152 & 39,183 & 38,932 & 40,890 & 40,578 & 40,691 & 40,691 \\
\hline Sicily & 104,569 & 110,329 & 104,918 & 105,304 & 112,631 & 113,172 & 115,297 & 119,807 & 118,166 & 121,429 & 126,717 & 133,564 & 139,313 \\
\hline IMED0C & 750,766 & 764,687 & 751,297 & 843,326 & 778,649 & 777,654 & 789,136 & 781,398 & 786,568 & 810,656 & 831,537 & 847,413 & 861,379 \\
\hline
\end{tabular}

Source: Own based on Eurostat data for the Balearics, Eurostat data for Sardinia except for the years 1991-1994, which were estimated by the author, Eurostat data for Corsica, taking data for 1991 for 1990 and 1995 for 1996 , WTO data for Malta, and Eurostat data for Sicily except for the years 1991-1994, which were estimated by the author. 
